\title{
Assessments of Geotechnical Condition of Landslide Sites and Slope Stability Analysis Using Limit Equilibrium Method in Goncha Siso Eneses Area, Northwestern Ethiopia
}

Azemeraw Wubalem ( $\square$ alubelw@gmail.com )

College of Natural and Computational Sciences, University of Gondar

Research

Keywords:

Posted Date: October 28th, 2020

DOI: https://doi.org/10.21203/rs.3.rs-97972/v1

License: (c) (i) This work is licensed under a Creative Commons Attribution 4.0 International License. Read Full License 


\section{Abstract}

Goncha Siso Eneses area is located in northwestern Ethiopia where landslide incidence is active. The landslide incidence in the area resulted in the devastation of 233.1 hectares of cultivated and non-cultivated land, death of eight people, demolition of five houses, displaced 90 households, and 45 households are under risk. The slope failure in this area also caused tilting of the power line, tilting of two houses, cracking of three-houses floor, failed of bridge and blocking of streams as well as springs. The purpose of this research is to evaluate the cause, failure mechanism, landslide distribution, geotechnical condition of the site, slope stability analysis, and factor of safety determination. Soil sampling, laboratory test, terrain characteristics, groundwatersurface manifestation characterization, groundwater depth determination, slope stability analysis, and factor of safety calculation were the most important activities employed in this research work. Using disturbed and undisturbed soil samples of the selected slope section, Atterberg limit (liquid limit \& plastic limit), natural soil moisture, unit weight, specific gravity, and shear strength parameters (cohesion \& internal friction angle) test were carryout as ASTM standard. The most marginal factor of safety of the area is determined based on the general limit equilibrium method that encompasses different methods inside using slope/w in GeoStudio 2018 software package considering various groundwater conditions for all selected slope sections. The factor of safety for all selected slope sections of the various method under different groundwater conditions is less than one. Based on the finding of field observation and laboratory results, landslide types (rock/soil slides, rock/earth fall, debris/earth flow, \& soil creeping) and landslide factors of the study area (slope angle, slope shape, slope modification, land use, groundwater, soil type, and rainfall) are determined. This research finds out that the soil has a great contribution to slope failure in the study area, besides the soil moisture and improper land use practice.

\section{Introduction}

The population growth rate around the world is alertly increasing from year to year. The demand for new lands for different purposes also increased in parallel. These bring slope geometry and environmental changes. The environmental and slope geometry changes also bring different natural hazards like slope instability, flooding, and drought. Among these, a landslide is one of the risky hazards that happens because of natural and manmade factors. Natural slope, which has been stable for many years, might befall due to change in slope geometry, loss shear strength of slope material, and an external (Abramson et al. 2002). The natural slope will also fall due to the combined effects of intense rainfall, steep topography, and soil condition (Thielen et al. 2005). Landslide is common in countries, which have fragile topography, complex geology, active gully and riverbank erosion, intense rainfall, and improper land utilization practice like Ethiopia. These conditions caused the country to have been influenced by landslide incidence frequently. The study area is a part of northwestern Ethiopia, which has been severely affected by landslide incidence. The landslide can cause damage to huge engineering structures, infrastructures, farmlands, villages, human beings, can block river channel, and road corridors. These all directly and indirectly retards the socioeconomic growth of the countries around the world, particularly in developing countries like Ethiopia. In 2018, rainfall trigger landslide caused the death of 62 people, 30 people have injured, 5,091 households have displaced, damages to houses and wide cultivated farmland and non-cultivated land in a different part of the country (Wubalem and Meten 2020). The landslide in the study area also caused damage in 233.1-hectare farmland, the death of eight people, one animal, destruction of five houses, block river channel, and springs. To minimize these damages due to a landslide, the various techniques have developed like qualitative (expert based/heuristic approach) and quantitative (statistical and deterministic/geotechnical approaches) that helps to identify the landslide-prone area in a given region. However, each technique has its merit and demerit. The statistical approach is important to determine the spatial distribution of landslide and its relationship with different conditioning and triggering landslide factors. These methods are also important in areas, where geotechnical data-scarce and the area is relatively large. However, this method did not provide a factor of safety, which provide information about the slope material. This limitation can solve using geotechnical approaches. The geotechnical approach is best when the area is small and accessible. It provides a numerical value that explains the inherent condition of the slope material, unlike statistical approaches. However, it is expensive and time-consuming.

Slope stability analysis using the limit equilibrium method is an important activity that helps us to check the slope stability condition by calculating the factor of safety from the ratio of resistance to driving force. Slope stability analysis can perform using limit equilibrium and finite element numerical methods. The limit equilibrium method is one of the oldest and the best well- 
known numerical methods that has been using routinely in geotechnical engineering work because of its simplistic and accuracy results (Carol et al. 2014). However, it cannot help to determine the response of the ground under stress. For this purpose finite element method is preferable. Furthermore, limit equilibrium method is better when the analysis not expected material response under stress whereas the finite element method is appropriate when the analysis considers mechanical responses of the materials (Carol et al. 2014). Hence the main objective of the present work is to characterize the geotechnical properties of soil and to calculate the factor of safety on failed slope section, general limit equilibrium method that encompasses various methods inside because of the assumption of inter slice force and the equation of statics have been employed.

\subsection{Overview of the Study Area}

\subsubsection{Description of the Study Area}

Goncha Siso Eneses area is located in Northwestern Ethiopia and can access through Addis Ababa - Dejen - Gundeweyin Mota asphalted road (Fig. 1). However, it is important to use a gravel road to reach the exact landslide sites. The area is bounded in between $37.9^{\circ} \mathrm{E}$ to $38.39^{\circ} \mathrm{E}$ longitude and $10.8^{\circ} \mathrm{N}$ to $11.06^{\circ} \mathrm{N}$ latitude. It has covered by scattering small bushes and a large tree. Goncha Siso Eneses area has characterized by tropical $(<1,830 \mathrm{~m})$, subtropical $(1,830-2,440 \mathrm{~m})$ and cool $(>2,440 \mathrm{~m})$ climate zone. Annual rainfall varies from $762 \mathrm{~mm}-1,824 \mathrm{~mm}$. The annual rainfall distribution showed pronounced seasonality with the heaviest rainfall being in July and August. The mean temperature of the area is $18.50 \mathrm{cc}$ with a mean minimum and maximum daily temperature of $11.400 \mathrm{c}$ and 25.50 0c respectively (Ermias 2015).

The Ethiopian highland is the results of the past geological and erosional process and marked by variable topography with landform of the steep hillslope, plateau and deep incised gorge/valley (Kifle 2013). Goncha Siso Eneses area is one part of the highland of Ethiopia, which characterized by mountain peaks, deep gorge /valley, plateau, and undulating topography with minimum 1, 198 m and maximum 3,199 m elevation.

\section{Methods}

\subsection{Data Collection}

Google Earth Image interpretation, soil sampling, soil laboratory testing, geotechnical (Limit equilibrium) analysis are followed to achieve the present research work. In this research, relevant and available data like a topographic map, DEM (30 m x $30 \mathrm{~m}$ resolution), Landsat 7 image, geological report and map, metrological data, borehole data, and landslide inventory have collected. These data were collected from Ethiopian Mapping Agency, Earth Explorer, United States Geological Survey (USGS), Geological Survey of Ethiopia (GSE), Ethiopian National Metrological Agency, Amhara Water Well drilling Enterprise (AWWDE), field survey, and Google Earth image interpretation, respectively.

\subsection{Satellite Image Interpretation}

Satellite images of the study area were analyzed and interpreted to identify the spatial distribution of landslide in the area. This is performed using Google Earth Imagery analysis tools.

\subsection{Landslide Inventory Mapping}

The landslide inventory map of the study area is prepared using intensive fieldwork and detail Google Earth Imagery interpretation using the time slide series in the tool. Then the final landslide inventory map is prepared using GIS software.

\subsection{Soil Sampling and Laboratory Tests}

Both disturbed (4) and undisturbed ( 8 ) soil samples have taken from four failed slope sections at the depth ranges of 120$280 \mathrm{~cm}$ on a scarp side of the landslide in Gete Semane, Debre Yakob, Debre Birhan, and Tora Meda areas. These samples have taken to Bahir-Dar Institution of Technology Soil Laboratory.

From these samples, atterberg limit (liquid limit and plastic limit) test, specific gravity, unit weight, moisture content, and direct shear strength (cohesion \& internal friction angle) tests were performed. The general activity in soil laboratory tests has summarized in Fig. 3. 


\subsection{Slope Stability Analysis}

For slope stability analysis, eight undisturbed soil samples were prepared and tested using direct shear strength test equipment. The shear strength parameters and unit weight of each sample are determined. Using limit equilibrium methods, all possible safety factors of the selected failed slope section have been calculated based on half-sine inter slice function, constant inter slice function, piezo-metric line, and Mohr's Coulomb failure criteria.

\section{Lithological And Groundwater Condition Of The Study Area}

\subsection{Lithological Condition of the Study Area}

Ethiopia has consists of Precambrian rocks, Paleozoic - Mesozoic sedimentary rocks, Cenozoic volcanic rocks, and recent sediments (Mohr 1983). The basement rocks are distributed in northern, western, southern, and eastern parts of the country whereas the Paleozoic - Mesozoic sedimentary rocks dominantly found in Abay, Mekele, and Ogaden basin. The Cenozoic volcanic rocks of Ethiopia have been classified as Trap series and Aden series volcanic rocks. However, the current study area belongs to the trap series of volcanic rocks associated with the shield volcano. Traditionally, these trap series basalts have been classified into Ashengi (Eocene), Aiba (32-25), Alaji (32-15 Ma), and Termaber (30-13 Ma), (Mohr 1983; Mohr and Zanettin 1988). Recently, Ethiopian volcanic rocks have also been classified as Basel basalt sequence (Ashengi formation), Upper basalt sequence (Aiba, Alaji, and Termaber formation), Quaternary Scoria basalt, and Broad base volcanic shield volcano capping the plateau. However, the study area belongs to the Basel and upper basalt sequence. The upper basalt sequence has marked by successive massive cliffs, a low degree of weathering, cliff-forming topography, frequent lacustrine deposit, columnar jointing, and cliff-forming topography with a flat top and high permeable lithology with spring emanation in Aiba, Alaji, Tarmaber, and shield volcano respectively. However, the Basel basalt sequence has characterized by a high degree of weathering and fracture as well as some intercalation of the tuff unit. This condition is suitable for water infiltration into the ground and causes the slope movement in different parts of the country. The study area also contains loss of recent soil sediments including residual soil, colluvial soil, and alluvial soil deposit on the plateau, slope toe, and river plain. Even though the rock units in the study area covered by thick residual reddish to dark unconsolidated soil deposit with depth ranges of 0-12 $\mathrm{m}$, the rock units are identified at gully and stream erosion, hillside and road cut exposure. Thus, six types of lithology have identified using detailed fieldwork such as residual soil, alluvial soil deposit, colluvial soil deposit, tuff, slightly weathered basalt, and highly weathered basalt. Residual soil is dominantly found in most parts of the study area. Its color ranges from reddish to dark color with homogenous gradation that formed by disintegration and decomposition of the underline basalt rock and intercalated tuff rock unit. This unit is dominantly found in central, southeast, and southwest parts of the study area and covered $18.8 \%$ of the area (Fg 2). This unit is severely affected by gully and surficial erosion. The second unit is Alluvial soil which is a transported type of soil deposit that founds dominantly along the riverbank and flood plain. It distributed spatially in the western and southwestern parts of the study area that covered a very small portion of the area. The alluvial soil deposit consists of various grain size that ranges from cobble to fine-grained soil particles. This unit ranges from brown to gray color. The depth of this unit ranges from 5-15 m. The third unit is colluvial soil, which is an unconsolidated and erodible soil deposit. It consists of very coarse to very fine soil particles. Colluvial soil deposit has dominantly found at the slope toe of Gete semane, Ineget, and Angot area. This unit was formed by the action of gravity and landslide, which deposited at the slope toe of the study area. The fourth unit is highly weathered basalt, which has aphanitic and porphyritic texture. The color of highly weathered basalt is brown, reddish, dark gray weathered color, and black fresh sample color. Hence, the area is covered by loose unconsolidated residual soil deposit; it is exposed only on a stream, gully erosion, road, and hillside. This unit covered a large portion of the study area and contains rock fragments, fine and coarse soil particles formed by the surficial process. Red paleosol and unconsolidated tuff rock unit found associated with this rock unit. This unit is highly affected by the surficial process like weathering, and erosion. The springs are emanated at the contact of the paleosol and unconsolidated tuff rock unit. The fifth unit is slightly weathered basalt that has aphanitic texture, brown, gray, and dark color in weathered and fresh color respectively. This unit is exposed to the cliff-forming topography and is characterized by 
columnar joint and massiveness. It was covered by shallow soil mass and resulted in a shallow landslide in the area. The springs are emanated from the contact of this unit and the unconsolidated tuff rock unit. This unit contains top detached rock blocks and failed rock fragments at the toe of the slope. The six-unit is Tuff rock, which is found in the northeast, southeast, and central parts of the study area with a very small aerial extent. It is dark light and whitish weathered and fresh colors respectively. It is a highly weathered rock unit, which is exposed at a road cut, stream erosion, and hillside.

Table 1 Lithology area cover

\begin{tabular}{|llll|}
\hline SNO & Rock unit & Area in $\mathbf{k m 2}$ & area\% \\
\hline 1 & Slightly weathered basalt & 62.9 & 18.63019 \\
\hline 2 & Highly weathered basalt & 194.207 & 57.52168 \\
\hline 3 & Residual soil deposit & 63.34 & 18.76051 \\
\hline 5 & Alluvial soil deposit & 2.975 & 0.881158 \\
\hline 6 & Colluvial soil deposit & 14.202 & 4.206455 \\
\hline
\end{tabular}

\subsection{Groundwater Condition of the Study Area}

Ethiopia has a lot of perineal and in perineal rivers that sourced from the mountain peak and has diversified lakes as well as springs in the rift, plateau, and the hillside of the peaked mountain. The most important hydro stratigraphy units include resenting unconsolidated sediments, Cenozoic volcanic rocks, Mesozoic sedimentary rocks, and locally important basement rocks (Kebede et al. 2018).

However, the study area belongs to the tertiary volcanic rocks of the upper basalt and lower basalt of fracture highly productive aquifer. The groundwater aquifer zone of the study area ranges from very shallow to very deep zones and its main recharge source is rainfall that recharged through fast selective recharge from heavy rainfall and direct diffuse recharge through soil and root zones (Siefu 2010). From the local shallow and deep well borehole, the depth of the productive aquifer has determined that ranges from 0-65 m with static water level ranges from 5-41 $\mathrm{m}$. This indicated that groundwater in the study area is near to the surface and is susceptibility to volume fluctuation within various seasons. The fluctuation of the water level might affects the moisture content of the soil. This will be an aggravated slope stability problem. From fieldwork, 51 springs have been identified at the interface of soil to basalt rock and the contacts of basalt and tuff rock units. In the study area, most of the landslides have occurred close to the available springs.

\section{Landslide Inventory}

The Inventory data in the study area was collected using a detailed field survey and Google Earth image interpretation. As noticed in Google Earth image interpretation, landslide incidence in the study area is a common problem since 2006 and has impressed 13 Villages such as Ineget weyin weha, Gete Semane, Angot, Abare weha Tayita, Yewaye, Wendeye, Mahile Goncha, Inegode, Sekela Genbore, Debre yakob, Debre Birhan, Adise, and Fela Yegarida.

\subsection{Landslide in Gete Semane Village}

According to local people, the first small landslide with crack development was occurred in 2014, which forced to relocate one family from their village (Fig. 4a). According to local people, a small landslide in this village continuously occurred in the rainy season, and curved cracks developed from year to year. This village has been affected again by a reactivated landslide in 2018 (Fig. 4b) and caused damages in a house and 48 hectares of cultivated land that has been covered by various crops like maize, teff and bean and different fruits like coffee, almond, lemon, buckthorn, orange, and papaya. This slide has occurred due to stream erosion, gully erosion, man-made activities, and due to the presence of spring, heavy rainfall, and unconsolidated deposit. 
The type of slope failure in this village is soil slide with a width of $10-800 \mathrm{~m}$, depth of 1-15 $\mathrm{m}$, depletion zone of 1- $25 \mathrm{~m}$, runout distance of 18-950 $\mathrm{m}$, and accumulation zone of 0-800 m. Landslide in this village will pose risks in the future because various tension cracks have been developed continuously from the toe to the top parts of the slope with an average length of 1$241 \mathrm{~m}$ and depth of $0.1-0.3 \mathrm{~m}$. These cracks caused a change in the streamflow directly into the cracks. The flow of water into the crack has caused the slope material to saturate by raising the groundwater level. The saturation of soil material can weaken the strength of the soil and result in slope failure. Various technical remedial and preventive measures like plantation of the eucalyptus tree, fruits, rock riprap, and terracing were applied but it is not possible to stop land sliding because of imbalance in the driving force with the constructed support and the plantation was above the failure zone. This further adds weight to unstable slopes.

\subsection{Landslide in Yewaye (Yekimcha) Village}

According to the local people, this area was severely affected by a debris flow in 1961 because of intensive and prolonged rainfall and damaged in 15-hectare farmland with crops. According to the local people, various measures like a plantation, and terracing were applied. It was effective for many years but it has been reactivated in 2018 because of overgrazing of the steep slope area, weathering, surface erosion, river undercutting, intensive agricultural activity, irrigation, and heavy rainfall. Landslide in this area includes transitional soil slide, debris flow/fall, earthfall, and rockfall. Landslide in this area has a depth of $0.1-12 \mathrm{~m}$, scarp height of 0.1-75 m, an accumulation zone of 0-75 m, a width of 10-200 m, and a runout distance of 20-370 m. These landslides caused damages in six-hectare farmland that has covered by various crops and permanent fruits. According to the local people, a landslide in this area occurred after 57 years ago. This area is under the risk of land sliding in the future because many cracks with an average length of $10-20 \mathrm{~m}$ and depth of $0-0.25 \mathrm{~m}$ are developed parallel to the scarp.

\subsection{Landslide in Sekela Genbore}

Landslide in this village has occurred due to stream initiated gully erosion, removal of slope toe by the river since 6/8/2006 (Fig. 6B) as observed in Google Earth image interpretation. Starting from this year, the study area, stream formation, and gully erosion increased from year to year as can be observed from Google Earth image interpretation (Fig. 6B). A few years ago, a permanent and large gully has been formed. The stream has been removing the slope toe support during the rainy season. This caused curved crack development, and then the slope falls as a curved surface and slides down towards the stream. The moving material moved away by the flowing stream. In 2018, a large soil slide is occurred because of springs, gully and stream erosion, improper ditch design, overgrazing, intensive agricultural activities, weathering, and heavy rainfall. Landslide in this area includes transitional, rotational, weathered rockslide and ground subsidence related landslide with average landslide depth of 0.5-6 $\mathrm{m}$, the width of 15-300 m, depletion zone of 0.1-15 m, an accumulation zone of 0-360 m, and runout distance of 0-370 m. These caused damages in seven-hectare farmland with crops and five houses are under risk. Various measures like plantation of the eucalyptus tree, terracing, rock riprap, and gabion wall were applied, but it is not effective because the measures are not applied in their-appropriated location. Landslide in this area has been occurred since 2006 and active until 2018 due to the removal of the slope toe by the river undercutting during the rainy season.

\subsection{Landslide in Ineget Kebele/Village}

According to local people, the earth flow type of landslide occurred in 2018 in this village, which caused damages to two houses, the death of eight people, and destroyed the 2.5-hectare crop and permanent fruit covered farmland. In this area, slope failure has occurred at the soil-rock interface when the slope soils are fully saturated due to heavy and prolonged rainfall. This slope failure has initiated by agricultural activities, steep slope gradient, shallow colluvial soil deposit overlaid on fractured, and highly weathered basalt unit and triggered by heavy and prolonged rainfall. It has a runout distance of $900-910 \mathrm{~m}$ with an average width of $15-20 \mathrm{~m}$.

\subsection{Landslide in Tora Meda Village}

In this village, soil slide is predominantly found and caused the destruction of farmland that has covered by various crop types, eucalyptus trees, and fruit. In addition to this, more than five houses are at risk. The rotational slide occurred on thick unconsolidated soil because of the removal of slope toe by stream erosion and gully erosion. In Tora Meda area, landslide incidence is a common problem in Gofer and Yigagira area and has landslide dimensions with depletion zone of 1.5-12 m, accumulation zone of $0-20 \mathrm{~m}$, runout a distance of $11-300 \mathrm{~m}$, the width of 7-60 m and a depth of 1-12 m. 


\subsection{Landslide in Debre Yakob Village}

In this village, the landslide has occurred as soil slip with a curved failure surface because of stream erosion of the slope toe and spring emanation at the soil-rock interface. According to local people, a landslide in this village has been occurred since 2012 and is reactivated in 2018 that caused damages on two hectares of cultivated land, which was covered by "teff", wheat, chickpea, and eucalyptus tree. Since the soil is unconsolidated, less permeable, and has high water absorption, it has failed when the soil is fully saturated. Earth fall has occurred at the interface of soil and rock units. Hence, the soil at the top of the slope is unconsolidated and the interface rock is highly weathered, the slope materials have failed at any season as earth fall.

\subsection{Landslide in Inegode Village}

Inegode is one of the areas that has been severely affected by landslide incidence, especially along the Tigidar river catchment. Landslide in this village has occurred since 2006 and active still now. The rotational, transitional, rock toppling, rockfall, and talus fall are the common landslide in the area. It resulted in damages to farmland, crops, and eucalyptus trees. A landslide in this area has a depletion zone of $0.5-30 \mathrm{~m}$, an accumulation zone of 0-200 m, runout distance of 8-203m, a width of 6-289 m, and a depth of 0.75-6 m. Hence, the shape of the slope is concave upward, which can impound water during the rainy season and cause the groundwater level raised. Thus, various springs have been exposed at the various point of the slope toe and flow permanently. This causes a decrease in the shear strength of slope material and initiates large-scale landslide occurrence in the area. Most of the landslides in this area have occurred on thick unconsolidated colluvial deposits, which is overlaid on highly weathered basalt and unconsolidated tuff rock unit.

\subsection{Landslide in Debre Birhan Village}

Debre Birhan is one of the areas that have been severely affected by landslide incidence before 2006 (Fig. 10) and active still now as observed in Google Earth image interpretation. Landslide in this area is damaged three-hectare farmland with crops because of Bina river erosion of the thick unconsolidated soil deposit, agricultural activities, and the presence of erodible soil, springs, heavy and prolonged rainfall.

Landslide in this village has dominantly occurred as rotational soil slide in four sites of Bina river catchment. Different sizes of landslides have occurred along the river when the river channel is changed. The river channel is changed when the landslide blocked the old river channels (Fig. 10). The landslide in this site has a width of 20-120 m, a run-out distance of 1,990 m, a depth of 2-12 m, an accumulation zone of $4-10 \mathrm{~m}$, and a depletion zone of $1.5-6 \mathrm{~m}$. Although they tried to provide various treatments like a plantation, gabion walls, and rock riprap, it is not well effective. Because the preventive methods have not been provided based on the causative factors condition.

\subsection{Landslide in Angot Village}

Angot is one of the areas that have been severely affected by rockfall, debris, and earthflow types of landslide incidence. This slide is caused by heavy rainfall, spring, stream overflow, agricultural activities, river cut, slope shape, and slope escarpment. Since the area is characterized by steep escarpment and highly concave upwards, rainwater can be impounded and infiltered into the sloping ground, which is then exposed at the slope toe.

The flowing of shallow groundwater inside the slope causes slope material saturation, piping, and pore water pressure development. These all caused soil strength reduction and a slope material movement. Earthflow and debris flow are the common landslide incidence in the area but later the whole slope materials are developed tensional cracks, curved cracks, and uneven surface. The spring that was blocked by a landslide has been exposed at the slope toe and flows towards the river. This will also cause piping and slope toe erosion. The combination of all landslide caused damages in 120-hectare farmland that has covered by various crops and permanent fruits. The slowly moving ground was blocked the spring water and has been interrupted the irrigation activities.

\section{Result And Discussion}

\subsection{Soil Laboratory Test Result}




\subsubsection{Soil Moisture}

This test is used to verify the natural moisture condition of the failure slope section in the study area. The moisture content test was performed for an undisturbed soil sample of DB03, DY03, and TM03 of the slope section for eight samples at various depth intervals. The average moisture content of the selected slope section ranges from 16-18\% as can be seen in Table 3 .

Table 3

Soil moisture

\begin{tabular}{|lll|}
\hline Slope Section & Depth to which sample take $(\mathbf{m})$ & Moisture content $(\%)$ \\
\hline DB03BH1 & $1.8-2.2$ & 16 \\
\hline DY03BH2 & $2.1-2.8$ & 18 \\
\hline TM03ВH3 & $1.2-1.9$ & 17 \\
\hline
\end{tabular}

\subsubsection{Unit Weight of Soil}

Both moist and dry unit weight of the sample was determined from the laboratory test result of the undisturbed sample. This test is performed for eight soil samples that have been taken at different depth intervals. The result of the tests has been presented in Table 4.

Table 4

Unit weight of soil

\begin{tabular}{|lll|}
\hline Slope Section & Depth to which sample was taken $(\mathrm{m})$ & Average unit weight $(\mathrm{KN} / \mathrm{m} 3)$ \\
\hline DBBH1 & $1.8-2.2$ & 1847.5 \\
\hline DYBH2 & $2.1-2.8$ & 1841.3 \\
\hline TMBH3 & $1.2-1.9$ & 1844.3 \\
\hline
\end{tabular}

\subsubsection{Specific Gravity of Soil}

The specific gravity of soil in the selected slope section has been determined using a pycnometer with a specified temperature of distilled water. This specific gravity is also used for hydrometer analysis. Specific gravity can be calculated using the following equation. $G_{s}=\frac{W_{o}}{W_{o}+\left(W_{a}-W_{b}\right)}$. Where: $W_{o}-$ Weight of sample of oven-dry soil, $W_{a}$ - the weight of pycnometer filled with water, $W_{b}$ - the weight of a pycnometer filled with water and soil. The specific gravity of soils in the study area at selected slope sections ranges from $2.64-2.83$ (Table 5).

Table 5

Specific Gravity of soil

\begin{tabular}{|c|c|c|c|c|c|c|c|c|c|c|c|}
\hline DB03 & & & GS01 & & & TM03 & & & DY03 & & \\
\hline Trial & 1.00 & 2.00 & Trial & 1.00 & 2.00 & Trial & 1.00 & 2.00 & Trial & 1.00 & 2.00 \\
\hline Wo & 25.00 & 25.00 & Wo & 25.00 & 25.00 & Wo & 25.00 & 25.00 & Wo & 25.00 & 25.00 \\
\hline Wa & 99.45 & 97.86 & Wa & 100.06 & 101.62 & Wa & 99.41 & 99.46 & Wa & 99.86 & 96.56 \\
\hline Wb & 115.11 & 113.45 & Wwb & 116.10 & 117.91 & Wwb & 115.28 & 115.76 & Wwb & 115.66 & 112.43 \\
\hline Gs & 2.62 & 2.66 & Gs & 2.79 & 2.87 & Gs & 2.74 & 2.87 & Gs & 2.72 & 2.74 \\
\hline $\begin{array}{l}\text { average } \\
\mathrm{G}_{\mathrm{s}}\end{array}$ & 2.64 & & $\begin{array}{l}\text { average } \\
\mathrm{G}_{\mathrm{s}}\end{array}$ & 2.83 & & $\begin{array}{l}\text { average } \\
\mathrm{G}_{\mathrm{s}}\end{array}$ & 2.81 & & $\begin{array}{l}\text { average } \\
\mathrm{G}_{\mathrm{s}}\end{array}$ & 2.73 & \\
\hline
\end{tabular}




\subsubsection{Atterberg Limit Test}

Atterberg limit test was performed for four-soil samples that have been taken from selected failed slope sections of DB03, DY03, TM03, and GS01 using Cone penetration and Casagrande rolling method for liquid limit and plastic limit according to ASTM D 4318-00. The other driving limits (plasticity index and liquidity index) have been derived from the results of atterberg limit test.

\section{Liquid Limit (LL)}

The liquid limit test has been done for the selected failed slope section using a cone penetration method as the standard of the ASTM D 4318 for $500 \mathrm{~g}$ soil fraction that passes through the sieve size of $0.425 \mathrm{~mm}$. It was conducted for four-soil samples within three trials at various moisture content of the soil. Using the moisture content and the cone penetration, $d$ the flow curve has been plotted and the liquid limit is determined from the moisture content corresponding to $d=20 \mathrm{~mm}$. The liquid limit of the soil in the study area ranges from $44-59 \%$ as indicated in Table 7. The liquid limit test is important to determine the behavior of fine-grained soil underwater. According to [5], the soil that has LL more than $50 \%$, grouped as high plasticity and LL in between $30 \%$ and $50 \%$ refers to the soil with intermediate plasticity or compressibility. If the LL is less than $30 \%$, the soil is with low plasticity. Based on the Cassagrande work, the liquid limit of the selected failed slope section in the study area is greater than $30 \%$, which falls under the region of intermediate and high plasticity and compressibility classes.

\section{Plastic Limit (PL)}

The plastic limit of the soil in the failed selected slope section of DB03, DY03, TM03, and GS01 is determined through repeated rolling of moist soil by hand on the ground glass plate until the soil crumbles as ASTM D 4318 standard and the result is presented in Table 7.

\section{Plasticity Index (PI)}

The plasticity index for the selected slope section is determined using the equation, PI = LL-PL. Based on the (Burmister 1949), degree of soil plasticity classification as indicated in Table 6, the selected slope section falls under the medium to high plasticity classes.

Table 6

Plasticity index comparison of the current work with Burmister plasticity index

\begin{tabular}{|c|c|c|c|c|}
\hline \multicolumn{3}{|c|}{ Burmister 1949} & \multirow[b]{2}{*}{ Sample site } & \multirow[b]{2}{*}{ Degree of the plasticity of the present work } \\
\hline PI ranges & Description & PI of present work & & \\
\hline 0 & Nonplastic & 9.395 & DY03 & Medium plasticity \\
\hline $1-5$ & Slightly plasticity & 21.12 & DB03 & High plasticity \\
\hline $5-10$ & low plastic & 11.25 & TM03 & Medium plasticity \\
\hline $10-20$ & Medium plasticity & 21.35 & GS01 & High plasticity \\
\hline $20-40$ & High plasticity & & & \\
\hline$>40$ & Very high plasticity & & & \\
\hline
\end{tabular}

\section{Plasticity Chart}

The plasticity chart is one of the most important relationships of the plasticity index and liquid limit which is developed by (Casagrande 1932). This chart helps us to separate silty soil from clay soil using the equation of $\mathrm{A}$ - line (PI $=0.73(\mathrm{LL}-20)$ ). When the plasticity index and the liquid limit cross below A-line, the soil is inorganic silt or organic silt/clay with low, medium, high or very high plasticity and compressibility depending on the liquid limit value or when they cross each other above A-line, the soil is inorganic clay soil with low, intermediate, high or very high plasticity and compressibility (Casagrande 1948). He also states the zone of plasticity and compressibility based on the liquid limit of the various soil mass. When the $L L>50 \%$ the soil will have high plasticity and compressibility. If $L L<30$, the soil will have low plasticity and compressibility but if $30<L L<50$, the soil will have 
intermediate plasticity and compressibility. Based on the Cassagrande's expression, the present soil plasticity index is fall below A- a line of inorganic silty/organic clay soil with intermediate to high plasticity and compressibility (Fig. 12). As a result of the liquid limit indicated in Table 7, liquid limits for all sites are greater than $30 \%$. This shows that the soil in all sites has high expansion and shrinkage potential when they gain and lose water. From the plasticity chart, the plasticity index (PI) values of the study area fall under the silty of intermediate and high plasticity zones. This confirms the high expansion and shrinkage potential of Getesemane, Debre Brhan, and Debre Yakob areas. Soils in Tora Meda are characterized by red to dark soil with intermediate plasticity whereas soils in Debre Yakob and Getesemane are characterized by red to brown color with high plasticity. Soils in Debre Birhan are characterized by red to dark gray color with high plasticity.

\section{Liquidity Index (LI)}

Using liquid limit (LL), plastic limit (PL), and natural moisture content (w) result, the liquidity index of the soils for the selected failed slope section is calculated using the following formula.

$$
L I=\frac{w-P L}{L L-P L}
$$

Liquidity index is the measure of soil strength which depends on the moisture content (Kalikin 2017). If $\mathrm{LI}<0$, the soil will have high strength and behaves as brittle deformation with a semisolid state if $0<\mathrm{LI}<1$, the soil is in a plastic state with intermediate strength and it can respond plastically under the application of stress but if $\mathrm{LI}>1$, the soils are in liquid state with very low strength and can respond as a viscous material. Based on the (Kalikin 2017), the liquidity index values of soils in the study area are greater than 1 as shown in Table 7, which is in a liquid state with very low strength.

\section{Compression Index}

The compressibility of soil is one of the engineering properties of soils that can be determined using the odometer test but it is time-consuming, expensive, and requires undisturbed soil samples. The compression index has a good relationship with a liquid limit, plasticity index, and shrinkage index (Skempton 1944; Sridharan and Magaraji 2000). In this study, the compressibility condition of the soil was estimated using atterberg limit test. The compression index of the selected slope section of the study area was calculated using both the value of liquid limit and plasticity index values using the formula that has been used by (Skempton 1944; Sridharan and Magaraji 2000) i.e., Cc = 0.007 (LL-10) and Cc = $0.014(\mathrm{Pl}+3.6)$.

Using the relationship of compression index (Cc), liquid limit, and a plasticity index value, linear regression graphs have been plotted in Fig 12. The result of both liquid limit and plasticity index linear regression graph is indicated that both variables have a good relationship (Fig 12). As indicated in Table 7, the compression index is increased as the liquid limit, and plasticity index values are increased. Therefore, from this relationship, we can conclude that the higher the liquid limit and plasticity index, the higher will be the compressibility potential of the soil. The soils in selected failed slope sections of DB03, TM03, DY03, and GS01 have been grouped into intermediate and high compressibility by referring plasticity chart in Fig 13.

Table 7

Atterberg Limit Test Results

\begin{tabular}{|lllllll|}
\hline Slope Section & $\mathbf{( P L )} \%$ & LL) $\%$ & PI $\%$ & LI & Cc = 0.007(LL-10) & Cc = 0.014(PI+ 3.6) \\
\hline DY03 & 45.73 & 55.1 & 9.395 & 13.1 & 0.3157 & 0.18 \\
\hline DB03 & 34.48 & 55.6 & 21.12 & 14.4 & 0.3192 & 0.35 \\
\hline TM03 & 33.6 & 44.85 & 11.25 & 14.0 & 0.24395 & 0.21 \\
\hline GS01 & 37.5 & 58.6 & 21.35 & & 0.3402 & 0.35 \\
\hline Note: PL- plastic limit, LL - liquid limit, PI - plasticity index, LI - liquidity index, A - activity and Cc - compression index \\
\hline
\end{tabular}

Page 10/37 


\subsubsection{Direct Shear Strength Test}

In this study, shear strength parameters like cohesion and angle of internal friction in the selected failed slope sections have been determined from the direct shear strength test as shown in Table 8.

Table 8

Average value of shear strength parameters of shear strength test results

\begin{tabular}{|llll|}
\hline Slope Section & Depth to which sample was taken $(\mathrm{m})$ & Cohesion $(\mathrm{KN} / \mathrm{m} 2)$ & The angle of internal friction(Degree) \\
\hline DBBH1 & $1.8-2.2$ & 29 & 20 \\
\hline DYBH2 & $2.1-2.8$ & 24.3 & 22 \\
\hline TMBH3 & $1.2-1.9$ & 24 & 22.3 \\
\hline
\end{tabular}

\subsection{Slope Stability Analysis}

The slope stability analysis in the selected slope section is performed based on the input data (cohesion, internal friction angle, unit weight of soil, and groundwater condition using slope/w methods as can be seen in Fig. 23.

Table 9

Input parameters for slope stability analysis

\begin{tabular}{|c|c|c|c|c|}
\hline $\begin{array}{l}\text { Slope } \\
\text { Section }\end{array}$ & $\begin{array}{l}\text { Unit weight } \\
\text { (KN/m3) }\end{array}$ & $\begin{array}{l}\text { Cohesion } \\
(\mathrm{KN} / \mathrm{m} 2)\end{array}$ & $\begin{array}{l}\text { The angle of internal } \\
\text { friction(Degree) }\end{array}$ & Groundwater condition \\
\hline \multirow[t]{3}{*}{ DBBH1 } & 1847.5 & 29 & 20 & At great depth/Dry Slope \\
\hline & 1847.5 & 29 & 20 & Surface \\
\hline & 1847.5 & 29 & 20 & $\begin{array}{l}5 \text { m depth within slip } \\
\text { surface }\end{array}$ \\
\hline \multirow[t]{3}{*}{ DYBH2 } & 1841.3 & 24.3 & 22 & At great depth/Dry Slope \\
\hline & 1841.3 & 24.3 & 22 & Surface \\
\hline & 1841.3 & 24.3 & 22 & $\begin{array}{l}5 \text { m depth within slip } \\
\text { surface }\end{array}$ \\
\hline \multirow[t]{3}{*}{ TMBH3 } & 1844.3 & 24 & 22.3 & At great depth/Dry Slope \\
\hline & 1844.3 & 24 & 22.3 & Surface \\
\hline & 1844.3 & 24 & 22.3 & $\begin{array}{l}5 \text { m depth within slip } \\
\text { surface }\end{array}$ \\
\hline
\end{tabular}

For the calculation of factor of safety using slope/w software, the first task is to determine the input parameters followed by defining geometry, region/material, pore water pressure, and trial slip surface. These can be described in the following sections.

\subsubsection{Geometry}

Defining a working area with appropriate geometry, scale and unit are the most important activities to be done in slope stability analysis. This is the process to define the physically admissible ideal slope geometry of the study area. The geometry of an ideal slope was defined using points and polygons based on the scale of 1 to 2 and $15 \mathrm{~m}$ slope height. If these points or polygons are 
not defined in the correct position, our model will be wrong. It needs great care to define this ideal geometry as illustrated in Fig. 14.

\subsubsection{Material}

The material statement is one of the key elements in slope/w analysis. Various ways are available to define material in the slope stability analysis like Mohr's coulomb, undrained strength, and bedrock (impenetrable material) which depends on the data that we have for the analysis. In the present work, Mohr-Coulomb is used. This includes the unit weight of soil mass, cohesion, and internal friction angle. Based on the field observation and laboratory test result information, the soil in the study area is more or less homogeneous. Therefore, the material of the region was assumed to a homogeneous.

\subsubsection{Pore Water Pressure}

Defining the pore water pressure is one of the key elements in any slope stability analysis. Most of the time, slope instability is faced because of the presence of pore water pressure in a given slope soil, therefore, a proper definition of pore water pressure regime is an essential component of slope stability analysis. This is mostly defined as piezometric line/s even if other methods of drawing are available. In this case, the pore water pressure can be determined from each slice base using height from slice base to piezometric line and unit weight of water.

\subsubsection{Critical Slip Surface}

In slope stability analysis, defining the critical potential slip surface is a very important step to get a minimum safety factor in a selected slope section using slope/w software. This can be performed by applying various searching options like entering and exiting, grid and radius, and block specified searching options (GeoStudio international 2004-2018). However, in present slope modeling, a critical slip surface is defined using enter and exit search options (Fig 15A). Because it is suitable and can be controlled by the user to adjust the slip surface search until the most critical slip surface is found. The critical slip surface location, extent, and shape can affect by the shear strength parameters.

\subsection{Factor of safety Computation}

\subsubsection{Factors of Safety Computation Using Ordinary Method (OM)}

As indicated in Table 10, this method was applied to calculate the factor of safety for selected failed slope sections under various groundwater conditions but it does not consider both normal and shear inter slice forces (Fig. 17), and not satisfy force in equilibrium (Fig. 22). Thus, it has not provided a factor of safety vs lambda graph because lambda is undefined (Fig. 22). The ordinary method satisfies only the equation of moment in equilibrium (Fig. 22). The force polygon closure is not possible as can be seen in the free body diagram in Fig. 17 and it has worsened force polygon closure from the crest of the potential slid mass to the toe of the sliding mass. As shown in the force polygon on slice numbers 8 and 23 , the force polygon closure is so poor. This can help to conclude that an ordinary method will not satisfy the overall force equilibrium. The factors of safety, calculated in this method, are unrealistic because the force polygon closure is so poor which means each slice is not in force equilibrium (Fig. 17).

\subsubsection{Factors of Safety Computation Using Bishop Method (BM)}

This method satisfies the overall moment equilibrium (Fig. 22) but it does not satisfy the horizontal force equilibrium. It has inter slice normal force but not inter slice shear force (Fig. 18). The force polygon closure was examined under similar slice number, which is good unlike ordinary. The sliding masses are almost in horizontal force equilibrium (Fig. 22). In the case of a factor of safety vs lambda graph, unlike the ordinary-simplified method, Bishop's simplified method factor of safety falls in the moment equilibrium curve when lambda is zero (Fig. 22).

\subsubsection{Factors of Safety Computation Using Janbu Simplified Method (JM)}

As indicated in Fig. 22, Janbu simplified method is the third limit equilibrium method that is satisfied only with the overall horizontal force in equilibrium. This method considers inter slice normal force like Bishop but it is ignored inter slice shear force (Fig. 19). As shown in Fig. 19, the force polygon closure in this method is better than the Bishop's simplified method. Thus, the slice of the slide mass is in horizontal force equilibrium. As designated in Fig. 22 and Table 10, the factor of safety of Janbu is lower than the Bishop simplified method because the force in equilibrium in the Jambu method is sensitive to inter slice shear 
force. Its ignorance of the inter slice shear force is the cause for reduction of a factor of safety in the Janbu simplified method, however, Bishop's simplified method satisfied the overall moment in equilibrium and as a result, it is not sensitive for inter slice shear force in a circular slip surface.

\subsubsection{Factors of Safety Computation Using Spencer Method (SM)}

This method satisfied both moment and force in equilibrium (Fig. 22). This method is considers both inter slice force (Fig. 20) and adopted the constant relationship between inter slice shear and normal force. As indicated in Fig. 20, it has quite good force polygon closure. Therefore, all slices are in force equilibrium. Unlike Bishop and Janbu, the value of lambda is greater than zero (Fig. 22). Meaning, this method has both inter slice shear and normal force because lambda is the ratio of inter slice shear to the inter slice normal force. This method is used to calculate two factors of safety like the factor of safety concerning moment and force equilibrium (Fig. 22).

\subsubsection{Factors of Safety Computation Using Morgenstern Price Method (MPM)}

This method satisfied the overall moment and force equilibrium (Fig. 22). This method has considered both inter slice force and has very good force polygon closure (Fig. 21). It is so important to calculate all possible factors of safety and to plot the factor of safety versus the lambda graph (Fig. 22). Unlike Spencer, this method is allowed various inter slice force functions. Therefore, this method is the best of all the other limit equilibrium methods. This method satisfies all equations of statics and is used to plot the factor of safety vs lambda graph that is so important to compare the factor of safety in each method (Fig. 22).

The factor of safety for all failed selected slope sections was calculated using slope/w software. As we know the factor of safety is the ratio of resistance force to driving force and it depends on the slope condition, material properties, and slope angle. As the result indicated in Table 10 and Fig, 22, a factor of safety for all failed selected slope sections is less than one

\subsection{Slope Stability Analysis results of Three Selected Slope Sections}

The minimum factor of safety and critical slip surface of three selected slope sections are calculated and searched for different limit equilibrium methods by considering various groundwater conditions as indicated in Fig. 25. All potential safety factors that are calculated at different groundwater conditions using various methods have been summarized in Table 10. 
Summary of Minimum Factor of Safety for each Slope Section

\begin{tabular}{|c|c|c|c|c|c|}
\hline \multirow{2}{*}{$\begin{array}{l}\text { Slope } \\
\text { section }\end{array}$} & \multirow[t]{2}{*}{ Methods } & \multicolumn{4}{|l|}{ A minimum factor of safety } \\
\hline & & $\begin{array}{l}\text { GWT at great depth/Dry slope } \\
\text { condition }\end{array}$ & $\begin{array}{l}\text { GWT on } \\
\text { Surface }\end{array}$ & $\begin{array}{l}\text { GWT at } 5 \mathrm{~m} \\
\text { depth }\end{array}$ & $\begin{array}{l}\text { Slope Status in all } \\
\text { condition }\end{array}$ \\
\hline \multirow[t]{5}{*}{ TM03 } & $\mathrm{OM}$ & 0.814 & 0.809 & 0.813 & Unstable \\
\hline & BM & 0.851 & 0.846 & 0.85 & Unstable \\
\hline & JM & 0.814 & 0.809 & 0.813 & Unstable \\
\hline & SM & 0.851 & 0.846 & 0.85 & Unstable \\
\hline & MPM & 0.852 & 0.847 & 0.851 & Unstable \\
\hline \multirow[t]{5}{*}{ DY03 } & $\mathrm{OM}$ & 0.802 & 0.798 & 0.801 & Unstable \\
\hline & BM & 0.839 & 0.833 & 0.838 & Unstable \\
\hline & JM & 0.802 & 0.797 & 0.801 & Unstable \\
\hline & SM & 0.839 & 0.834 & 0.838 & Unstable \\
\hline & MPM & 0.84 & 0.834 & 0.839 & Unstable \\
\hline \multirow[t]{5}{*}{ DB03 } & $\mathrm{OM}$ & 0.726 & 0.722 & 0.725 & Unstable \\
\hline & BM & 0.759 & 0.754 & 0.759 & Unstable \\
\hline & JM & 0.726 & 0.721 & 0.726 & Unstable \\
\hline & SM & 0.76 & 0,755 & 0.759 & Unstable \\
\hline & MPM & 0.76 & 0.755 & 0.76 & Unstable \\
\hline
\end{tabular}

\subsubsection{Possible landslide Factors}

From field observation, laboratory results, and local people interview, the most important landslide factors, which have identified are rainfall, land use, Groundwater, slope, slope modification, and loss resent sediments.

\subsubsection{Rainfall}

Slope failure has occurred in the middle, end of July, August, and September with intense and prolonged rainfall in the study area. As indicated in the bar graph of Fig. 24, the rainfall intensity varies from month to month. For instance, the rainfall intensity in July, August, and September are so high. The information that has gathered from local people interview, Natural soil moisture test result, liquidity index, and Google Earth image interpretation indicates, landslides in the study area have occurred related to heavy and prolonged rainfall. This shows that rainfall is one of the most important triggering factors for slope failure in the study area. As designated in Table 3, the natural soil moisture content of soil increase with depth for the selected failed slope section. This implies the fluctuation of soil moisture due to the effects of rainfall. This result shows, during the rainy season the moisture of soil increase and cause reduction unsaturated zone of the soil profile. This also causes a reduction of shear strength but the increasing weight on the slope and driving force. These all trigger the slope instability in the area. However, the presence of heavy and prolonged rainfall in a given region may not cause landslide unless other conditioning factors are available. In the study area, in particular, cool zones that have high rainfall but have not subjected to landslide incidence due to flat topography and the absence of slope modification. Therefore, rainfall by itself does not trigger landslide without the contribution of other factors like geology, soil depth, slope gradient, slope modification, vegetation cover, and vegetation type.

\subsubsection{Groundwater}


The groundwater aquifer zone of the area ranges from very shallow to very deep zones and its main recharge source is rainfall that recharged through fast selective recharge from heavy rainfall and direct diffuse recharge through soil and root zones. The groundwater depth varies from 0-65 m with static water level ranges from 5-41 m. This indicated that groundwater in the study area is close to the surface which has susceptible to volume fluctuation within various seasons. The fluctuation of the water level might affects the moisture content of the soil. This will be an aggravated slope stability condition problem. Groundwatersurface manifestation features like wet and flow springs have been observed in the field. Landslide in the study area has occurred close to the springs. The presence of springs on the surface informs us the area has shallow groundwater. Most of the spring's volume fluctuates in the summer and winter season. During the rainy season, their volume will increase. This can cause a reduction in the thickness of the unsaturation zone. The reduction of the thickness of the unsaturated zone can also heighten slope instability. However, during the dry season, their volume decreases and causes the soil mas to shrink its volume, which develops cracks that also cause a reduction to the shear strength of soil material in the slope. The factor of safety results at various groundwater levels is different which implies groundwater fluctuation has a fundamental effect on slope stability problem. Therefore, groundwater in the study area has a great role in slope stability.

\subsubsection{Land use/cover}

Landslide in the study area has occurred in lands that are intensively eroded by river or stream because of the removal of vegetation along the riverbank for agricultural purposes. Even though agricultural activity in the study area practice on a flat slope, it has a great effect on landslide occurrence because of the presence of gully and stream bank erosion. Settlement and deforestation are common on a steep slope of the study area. This increased the removal of soil by erosion and caused slope movement down a slope. The area, which has bare or scatters vegetation cover is susceptible to the landslide. However, the moderately vegetated area is less susceptible to a landslide because it reduced the power of rainfall in leaves intercept and infiltration due to evapotranspiration. In the study area, landslides have occurred in overgrazing land, bare to scatters vegetation cover, and along stream/river bank. This confirms that land use/cover has a great role in slope instability.

\subsubsection{Slope and modification}

The slope gradient of Debre Yakob, Debre Birhan, Tora Meda, Sekela Genbore, and Inegode have changed into steep slope through excavation (Debre Yakob), gully, and stream bank erosion. Thus, the landslide has occurred in a gentle to very gentle slope gradient. Therefore, landslides can occur at any slope gradient when required conditions fulfill. The steeper slope gradient of the study area also caused for the occurrence of rockfall, debris, and earthflow in Gete semane, Ineget, Yeawaye, Inegode, and Angot village. Besides, the slope gradient, the orientation, and the shape of the slope have also a great effect on slope stability problems in the study area. In the study area, landslides are common in concave and convex slope shape. This is because of the hydraulic and gravity effect of the concave and convex shape of the slope. The concave upward slope enhanced rainwater ponding and infiltration into the soil mass. This further enhances the reduction of shear strength of soil mass in a slope.

\subsubsection{Parameter and landslide Probability Relationship}

Characterization of the physical properties of the soil is important to deduce the engineering properties of soil at various conditions. For this purpose, atterberg limit test was performed. The liquid limit and plasticity index value of the selected slope sections are more than $35 \%, 9 \%$ and the plasticity index of soil falls under intermediate, high compressibility, and plasticity zones in the plasticity chart of Fig. 15.

The liquidity index of the soil is greater than 1 (Table 7) which is in a liquid state and characterized by poor strength. These showed that the soils would have high swelling and shrinkage potential. This implies, when the slope section is exposed to excess water, the soil will behave like a liquid and causes the slope instability problem. Based on the information from fieldwork and laboratory results, we can conclude that the soil in the study area is highly susceptible to a landslide. The compressibility index of a selected slope section was calculated using a simple linear regression relationship equation of the compression index with liquid limit and plasticity index. As the analysis in Fig. 14 showed, the liquid limit and plasticity index has good linear regression with a compression index. Therefore, the higher liquid limit and plasticity index in a given soil mass will have a high settlement. This also leads to slope instability under internal settlements of slope material. The factor of safety that has been calculated under various groundwater conditions of the selected slope section is less than one. This again confirms that the soil mass in the selected slope section is inherently unstable. Soil moisture is another key factor that controls slope stability. As soil

Page $15 / 37$ 
moisture results indicated in Table 3, it increases with depth. This is because of the infiltration of rainwater into the ground, which increases the groundwater table. This again causes a reduction of unsaturated soil zone and an increase in pore water pressure. This leads to a decrease in the shear strength of soil, which makes the slope unstable. Landslide in the study area has occurred during the rainy season. This further illustrates the increased moisture content of a soil mass has a great role in landslide occurrence. The role of groundwater in slope stability is so critical. Groundwater affects slope stability by increasing pore water pressure, increasing weight on a slope when the soil mass is fully saturated, decreasing effective stress, and loss of shear strength parameters. The factor of safety in all selected slope sections has been calculated by considering different groundwater conditions. As a result in Fig. 24 and Table, 10 showed, the factor of safety in the three-failed slope sections has decreased as the groundwater level rises. This further confirms that groundwater is one of the most important elements in slope stability analysis. The swelling nature of the soil in the study area causes an increase in the driving forces in combination with other factors. From Atterberg limit test result, the soil mass in the selected slope sections is indicated that soil mass has a swelling and shrinkage potential. This leads the soil mass to lose its strength when it loses and gains water. When the soil mass loses water, it can develop tension cracks on the top of the slope. This causes loss of soil strength when rainwater entered into the slope through this tension crack. From critical field observation, a landslide in the study area has occurred in highly and slightly weathered soil mass and rocks. Thus, weathering is one of the key processes that cause a reduction of the inherent strength of soil mass or rocks by mechanical, biological, and chemical processes.

\subsubsection{Comparison of the performance of All Limit Equilibrium Methods}

As indicated in Fig. 24, the factor of safety in each method is different except for Spencer and Morgenstern Price methods. Both Spencer and Morgenstern Price methods have been satisfied moment and force equilibrium but they differ in inter slice force function. The Spencer method (SM) has used constant inter slice force function while Morgenstern Price method (MPM) has used a various user-selected inter slice force function like half-sine, constant, trapezoidal, clipped - sine, and data point specified, but their factors of safety are more or less equal (Table 10). As indicated in Fig. 25 and Table 10, the factor of safety of Janbu's simplified method (JM) is less than Bishop's method (BM). This is because JM is sensitive to inter slice shear force in circular slip surface but BM is not sensitive for inter slice shear force for circular slip surface. When we compare the factor of safety of all methods, BM has a more or less similar safety factor with SM/MPM (Fig. 26 and Table 10). This is because it is not sensitive for inter slice force function in a circular slip surface. Among all methods, the MPM method is preferable in slope stability analysis because it provides a factor of safety with various user-selected force functions and it provides a factor of safety against the lambda graph that helps us to compare the factor of safety for different methods. Therefore, it is advisable to use MPM than the other limit equilibrium methods in slope stability analysis because it satisfies all equations of statics.

\section{Conclusion And Recommendation}

\subsection{Conclusion}

Based on the laboratory test result, the soils in the four selected failed slope sections have similar properties, which were more or less homogeneous. Thus, the soil mass in Debre Brhane, Debre Yakob, Tora Meda, and Gete Semane failed slope section have worse engineering behavior based on their atterberg limit test results. From the result of the higher value of liquid limit, plasticity index, liquidity index, and compression index, the soil mass in the failed slope section has higher swelling and shrinkage potential. As the higher value of atterberg and driving the limit result, we can conclude that the soil mass in the selected failed slope section has poor hydraulic properties. This can cause to increase in the volume of soil when it interacts with water and can develop pore water pressure. These all lead to an increasing driving force but decrease the resisting force. This again heightens the slope failure in the area. From the rainfall analysis, natural moisture content, local people interview, and Google Earth image time series interpretation, the present work finds out that rainfall is one of the most important landslides triggering factors in addition to other factors. The slope angle, slope shape, and slope geometry modification have a great role in landslide occurrence especially in Ineget, Debre Birhan, Angot, and Inegode villages. As usual, the steeper the slope, the higher will be landslide susceptibility however it might not be always true. A landslide can occur in a gentle slope due to slope geometry modification through natural and anthropogenic activity. This is true in the present study area, most landslides have occurred in gentle slope due to excavation and stream/riverbank erosion. Slope shape is another key element in the slope stability problem in the study area. The concave slope shape in the Angot and Inegode area enhanced rainwater ponding and infiltration of rainwater into the ground. This further aggravates the slope failure in this area. The factor of safety in the study area is less than 
one and decreases as the groundwater level raises. This insured that groundwater has a great role in slope stability problem and the soil mass in the selected failed slope section is worse inherently. Using different limit equilibrium methods, slope stability analysis performed and the selected slope is unstable at the present condition in which the factor of safety is less than one. The factor of safety of OM and JM has less than other methods but BM provides a factor of safety close to SPM and MPM. This is because even though BM is not satisfied with all equations of statics, BM is not sensitive for interslice shear force in a circular slip surface. Although SM and MPM have provided a similar factor of safety, MPM has allowed users to select a variety of interslice force functions unlike SPM, which has used only constant interslice force function. Therefore, MPM is the most preferable methods in slope stability analysis because it satisfied all equation of statics, consider interslice shear - normal force assumption used to plot factor of safety vs lambda graph, and allows users to select a variety of interslice force function.

\subsection{Recommendation}

Landslide susceptibility analysis without any preventive and mitigation measure is senseless in the scientific world. It has been known that landslide is the result of the combination of two or more landslide conditioning factors.

Based on landslide factors appropriated preventive and remedial measures might recommend. Hence, a landslide in the study area is happening due to the presence of different conditioning and triggering factors like gully and stream/riverbank erosion, overgrazing of land, deforestation, spring, rainfall, slope gradient, and slope shape.

Based on the implication of such factors the most important preventive and mitigation methods were suggested. These are land use management, vegetation cover, slope water management, and soil erosion management

\section{List Of Abbreviations}

ASTM- American Society for Testing and Materials

ASTM D- American Society for Testing and Materials, D- Miscellaneous Materials

DEM-Digital Elevation Model

g-gram

LL-Liquid Limit

PL-Plastic Limit

PI-Plastic Index

LI-Liquidity Index

w-water content of soil

Cc-Compression Index

DB03-Debire-Birhan Slope Section

TM03-Tora-Meda Slope Section

DY03-Debre-Yakob Slope Section

CL-Clay of Low Plasticity or Lean Clay

Cl-Clay of Intermidate Plasticity

$\mathrm{CH}-\mathrm{Clay}$ of High Plasticity, Fat Clay

Page 17/37 
OL-Organic Silt, Organic Clay

OH-Organic Clay, Organic Silt

ML-Silt of Low Plasticity

MI-Silt of Intermidate Plasticity

MH-Silt of High Plasticity, Elastic Silt

DBBH1-Debre-Brhan Slope Section Borehole 1

DYBH2-Debre-Yakob Slope Section Borehole 2

TMBH3-Tora-Meda Slope Section Borehole 3

GWT-Groundwater Table

GW-Groundwater

OM-Ordinary Method

BM-Bishop Method

JM-Janbu Simplified Method

SM-Spencer Method

MPM-Morgenstern Price Method

\section{Declarations}

\section{Acknowledgments}

First, I would like to thanks the almighty God who allowed me to accomplish this research work. I would like to thank University of Gondar, National Metrological Agency staffs, Geological Survey of Ethiopia, Goncha Siso Eneses wereda Administrative head office, disaster head office, natural resource management head office and the rural community for their finance, geological equipment, valuable data and continuous support during fieldwork respectively.

\section{Authors' Contributions}

All activities starting from the conception and design of the work, the developments of the models as well as the statistical analysis and interpretations of the results were done by me.

\section{Funding}

It is not applicable in this case.

\section{Availability of data and material}

All the datasets that have been used and analyzed during the current study are available from the corresponding author on reasonable request.

\section{Competing interests}

I have declared that there are no competing interests. 
Department of Geology, University of Gondar, Ethiopia.

\section{References}

1. Abramson, L.W., Lee, T.S., Sharma, S., and Boyce, G.M (2002) Slope Stability and Stabilization Methods. John Wiley \& Sons Inc. 712.

2. Busrmister, D.M. (1949) Principles and Techniques of Soil Identification, Proceedings, Annual Highway Research Board Meeting, National Research Council, Washington, D.C., 29: 402-434.

3. Ermias Teferi. (2015). Soil hydrological impacts and climatic controls of land use and land cover changes in the upper Blue Nile basin, Netherland. CRC Press/Balkema, 22-263.

4. Casagrande, A (1932) "Research of Atterberg Limits of Soils," Public Roads, 13 (8): 121-136.

5. Casagrande, A (1948) Classification and Identification of Soils. Transactions, ASCE, 113:901-930.

6. GeoStudio international Itd (2004 - 2018) Stability modeling with GeoStudio. Ed 6th, Calgary, AB, Canada, 9 - 252.

7. Kalikin, VN (2017) Soil mechanics, calculation, principle, and methods. Butterworth - Heinemann Elsevier. 64 - 72.

8. Kebede, Hailu, Crane, Ó Dochartaigh, and Bellwood-Howard (2018) Hydrogeology of Ethiopia. http://earthwise.bgs.ac.uk/index.php/Hydrogeology_of_Ethiopia has accessed on 03/29/2019.

9. Kifle Woldearegay (2013) Review of the occurrences and influencing factors of landslides in the highlands of Ethiopia with implications for infrastructural development. Mekelle University, Mekelle, Ethiopia. Journal of Muna, 5: 331.

10. Carol Matthews and Zeena Farook, Arup; and Peter Helm (2014) Slope stability analysis - limit equilibrium or the finite element method? Newcastle University, ground engineering, 1-7.

11. Mohr P. (1983). Ethiopian flood basalt province. Nature, Vol. 303: 577-584.

12. Mohr P, Zanettin B (1988) The Ethiopian flood basalt province. In Macdougall JD (ed) Continental flood basalts. Kluwer Academic, Dordrecht.

13. Skempton, A.W (1944) Notes on the compressibility of clays. Quarterly Journal of the Geological Society, London, 100 (2): $119-135$.

14. Thielen, A., Friedel, S., Plotze, M. and Springman, S.M (2005) A combined approach for site investigation in terms of the analysis of rainfall-induced landslides.

15. Siefu Kebede (2010) Groundwater in Ethiopia. Addis Ababa University, Ethiopia, 1.

16. Sridharan and H.B. Nagaraji (2000) Compressibility behavior of remolded fine-grained soils and correlation with index properties. Can. Geotechn.J., 37: 712 - 722.

17. Wubalem A.*, Meten M (2020) Landslide susceptibility mapping using information value and logistic regression models in Goncha Siso Eneses area, northwestern Ethiopia. SN Applied Sciences, Switzerland AG 2:807| https://doi.org/10.1007/s42452-020-2563-0

\section{Figures}




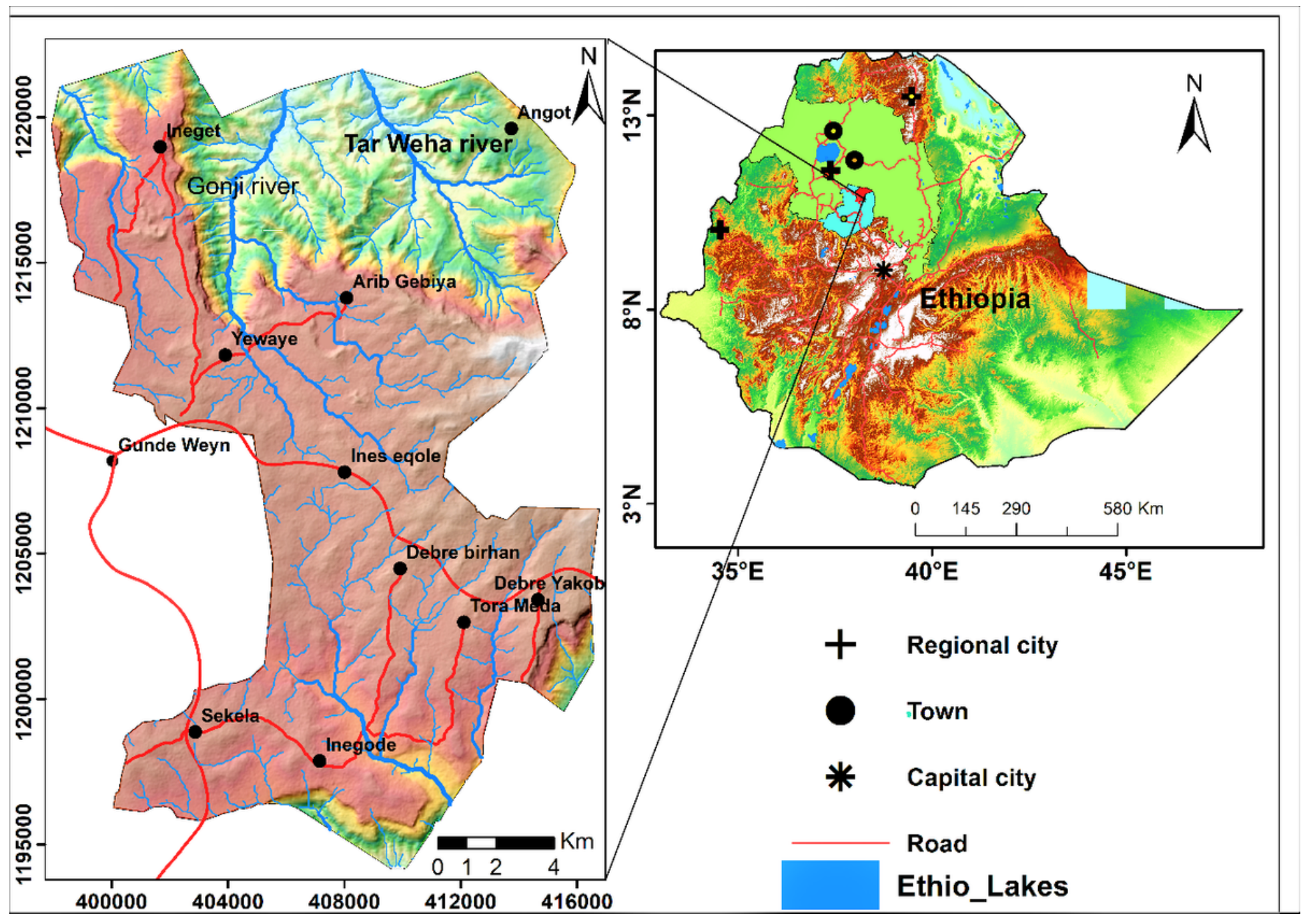

Figure 1

Location and Accessibility of the study area (Wubalem 2021) 


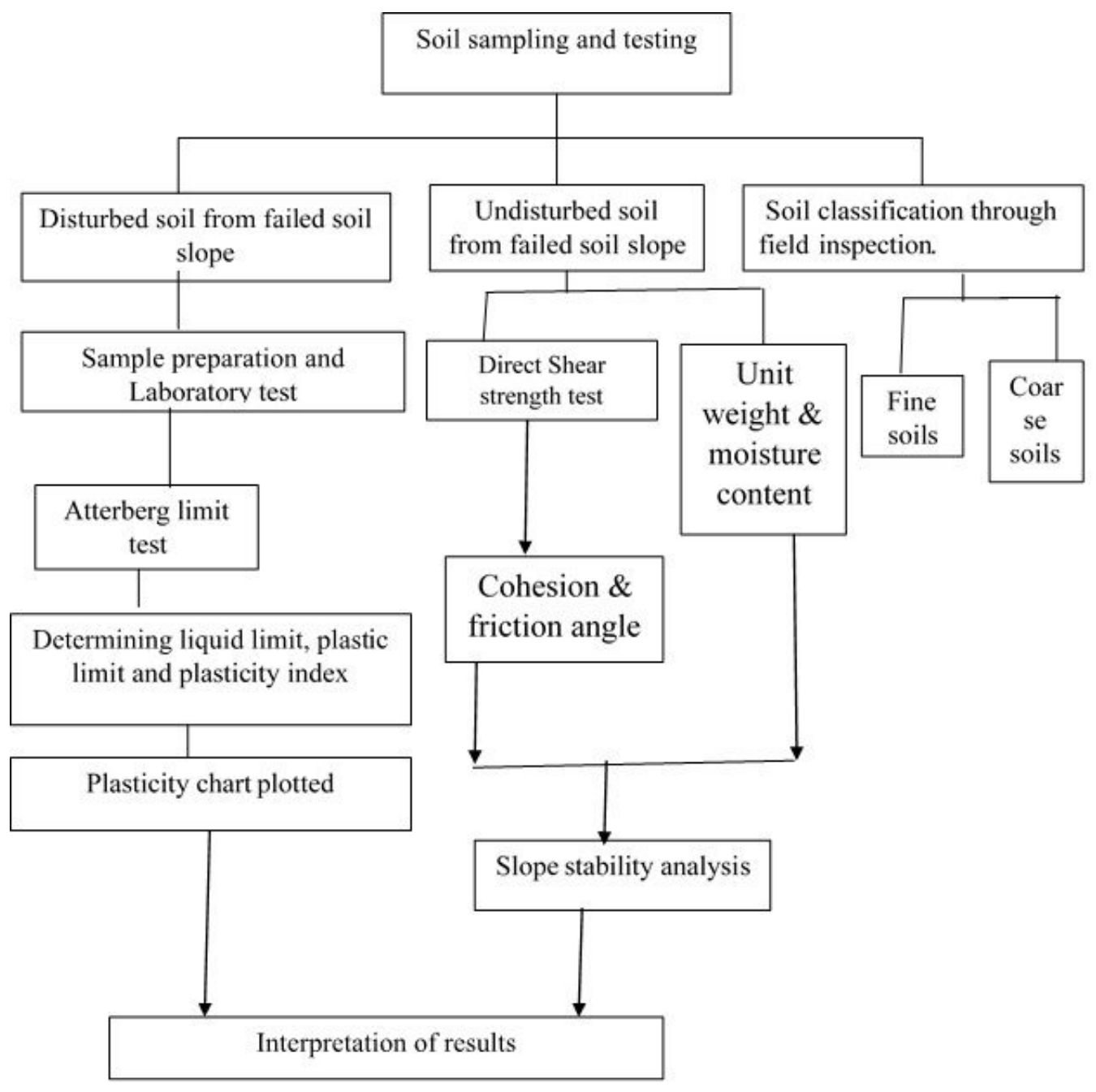

Figure 2

flow chart 


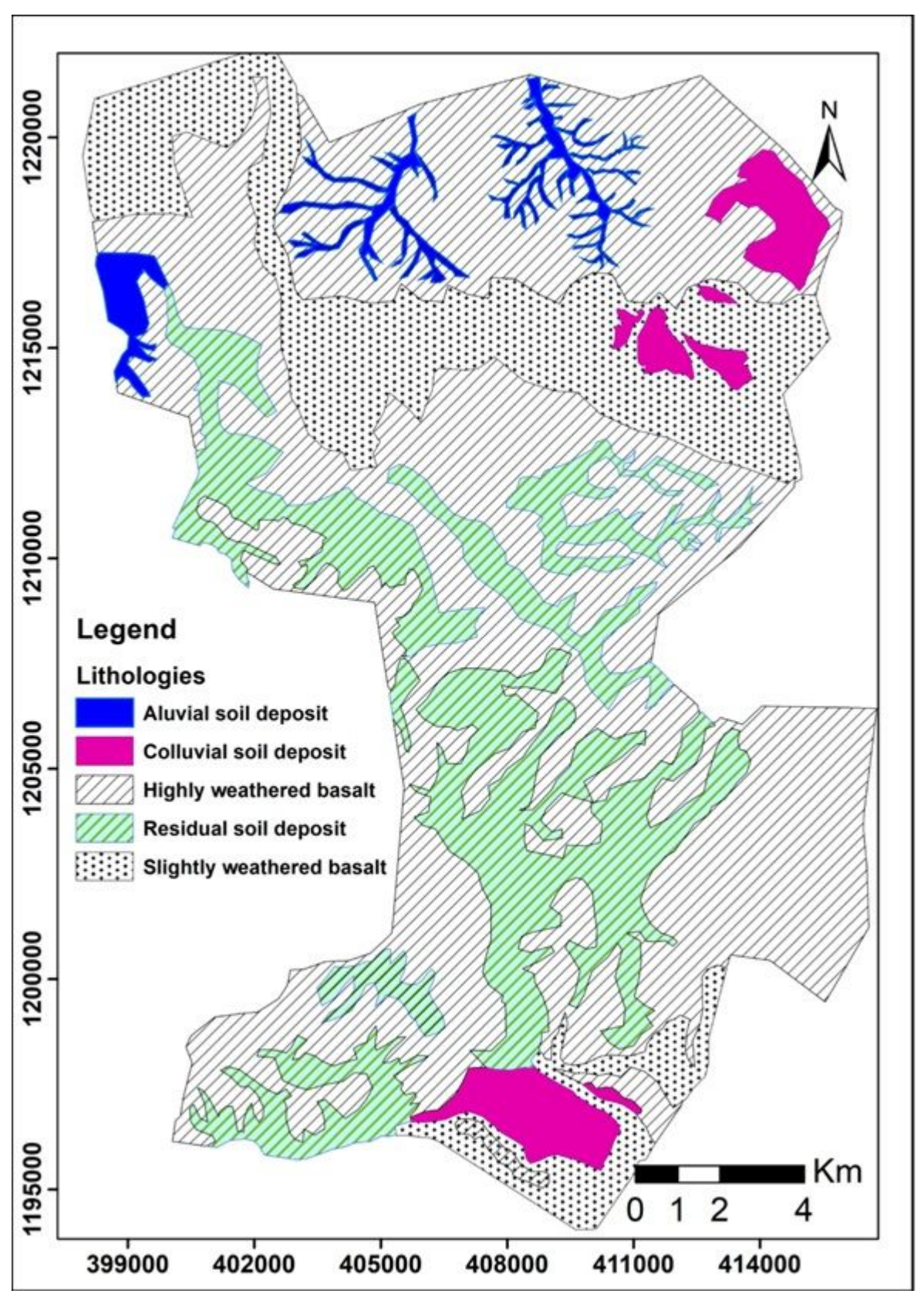

Figure 3

Lithological map 


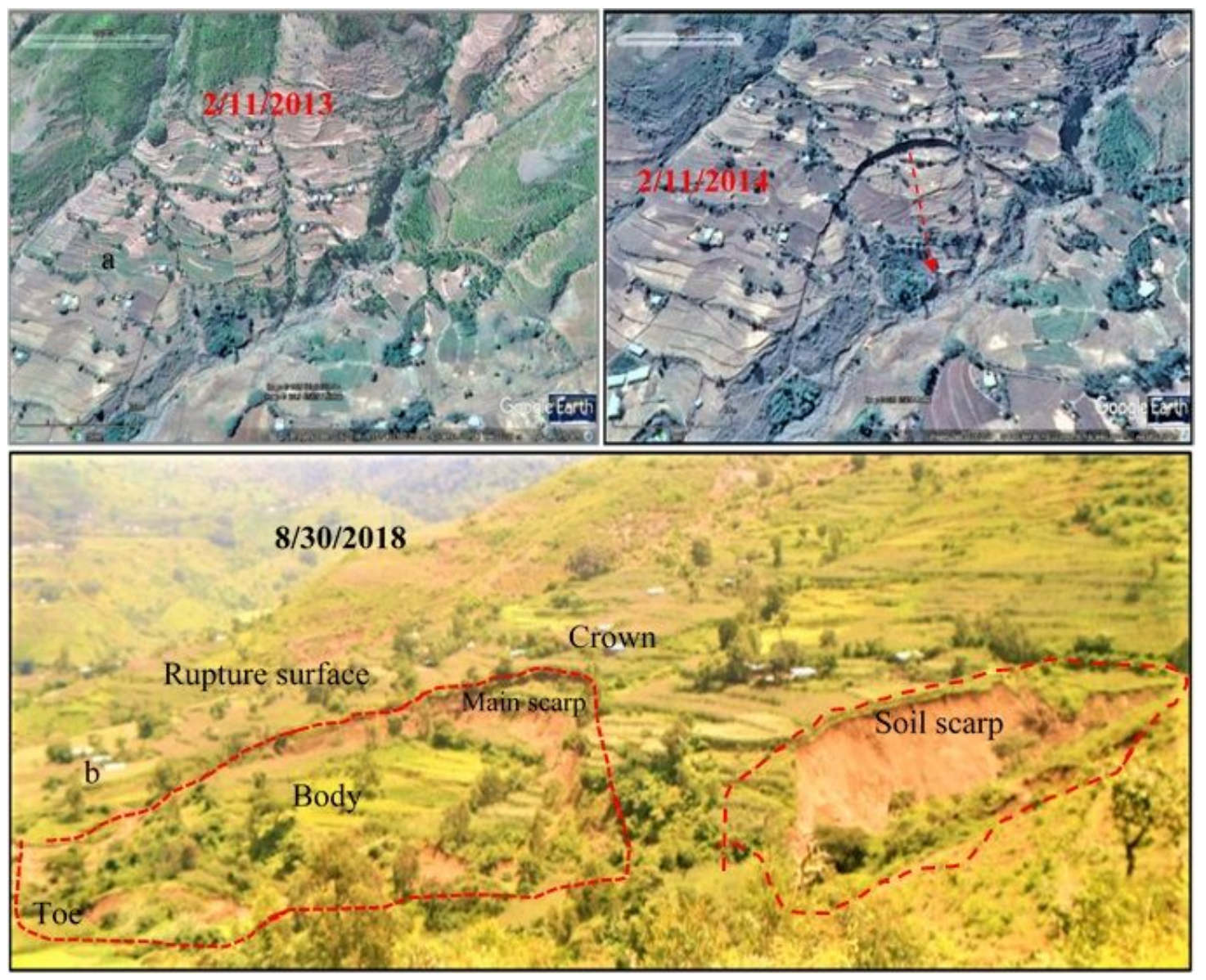

\section{Figure 4}

Soil Slide in Gete Semane

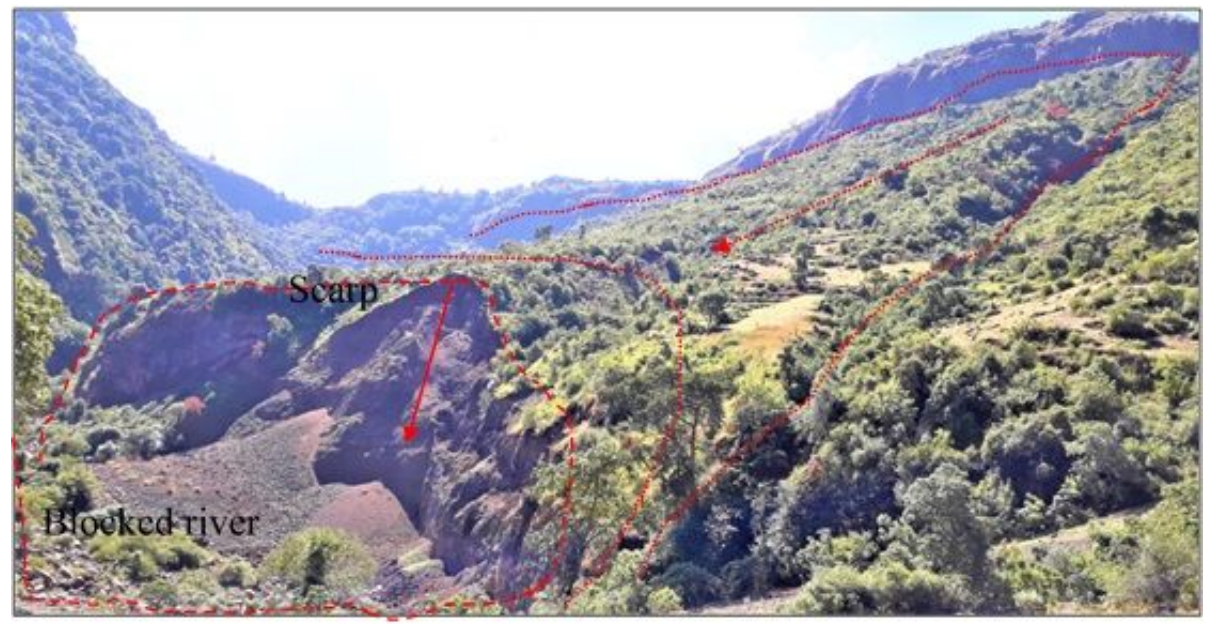

\section{Figure 5}

Earth fall and front view of large scale sliding 

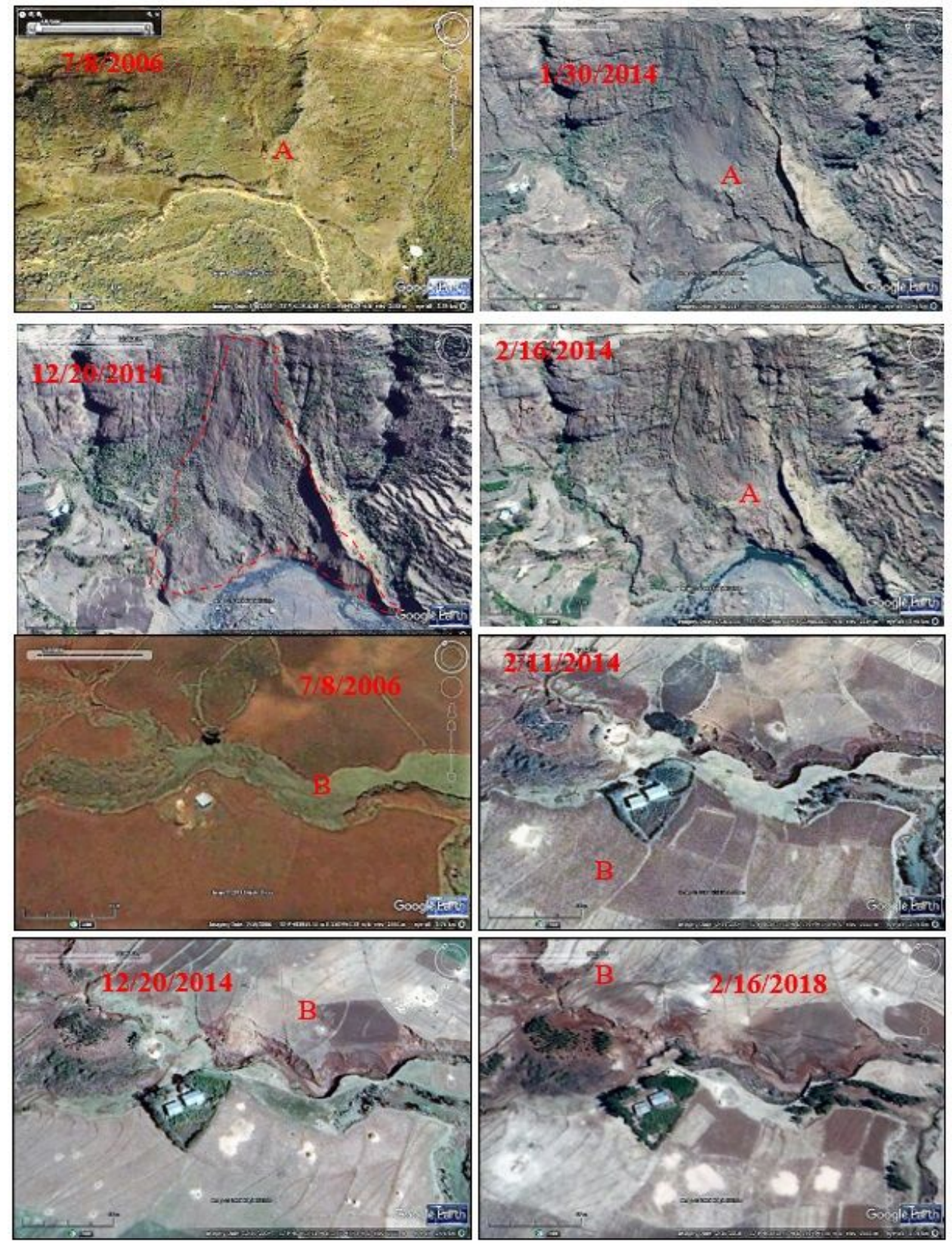

\section{Figure 6}

Time series landslide data from Google Earth image of Sekela Village B) in site 1 and A) in site 3 


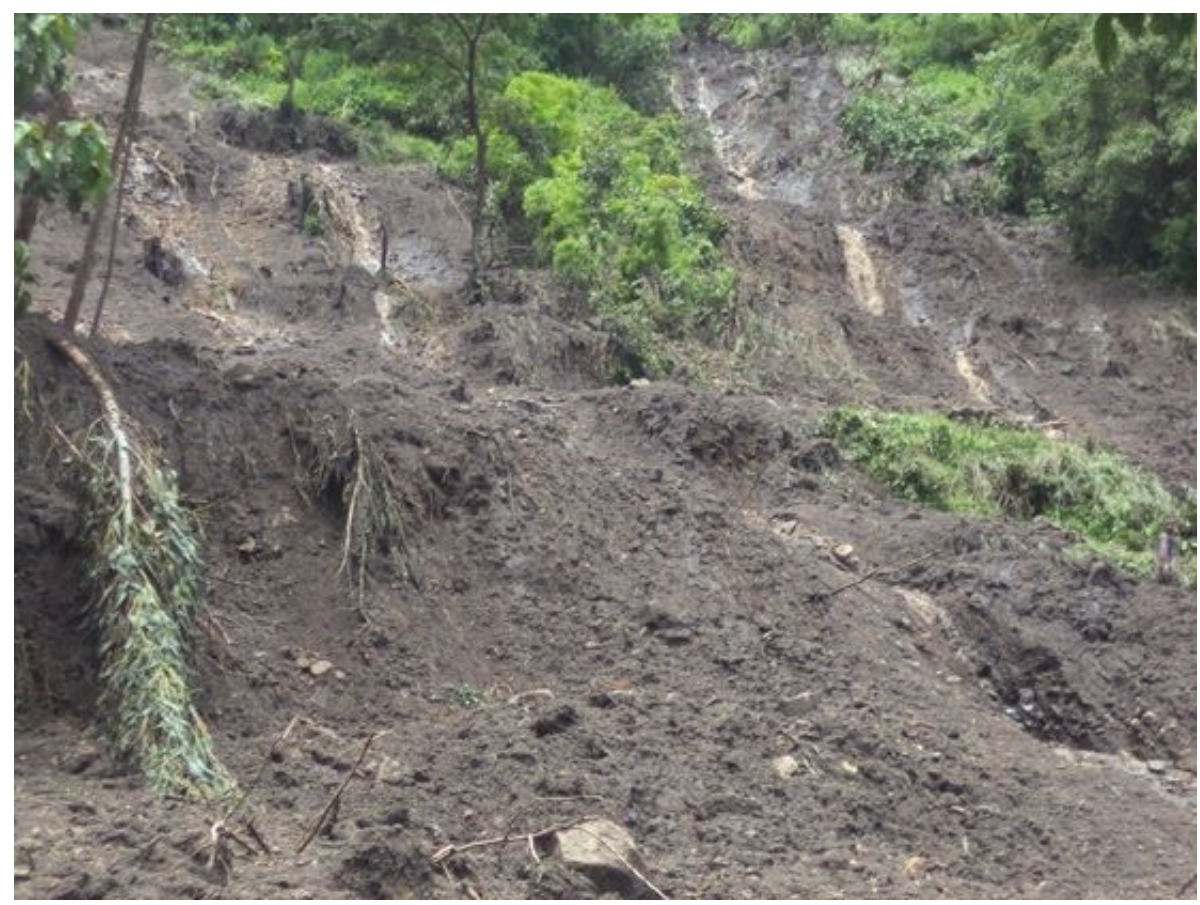

Figure 7

Earth flow in Ineget area

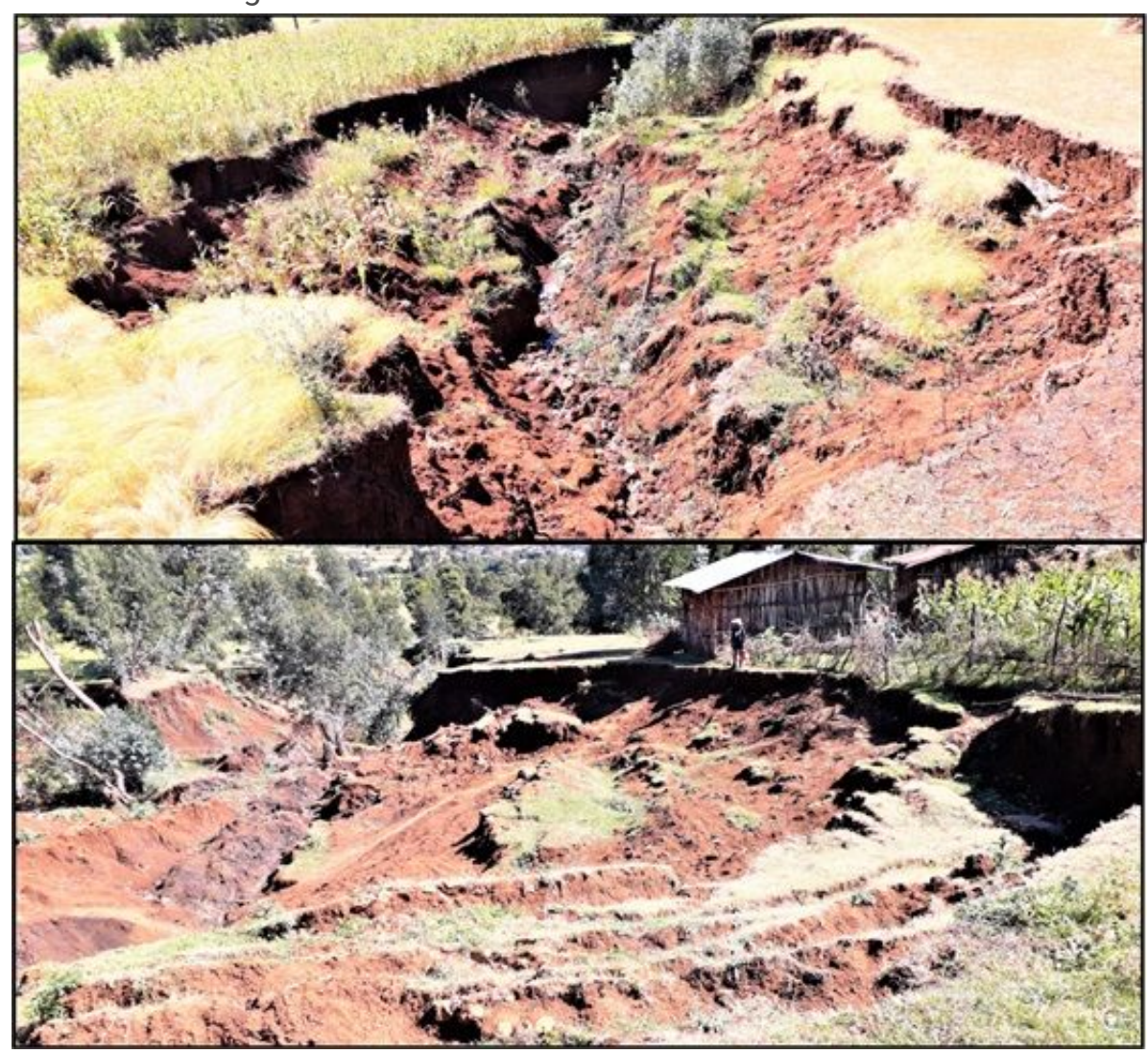

Figure 8

Soil slide in Tora Meda area 


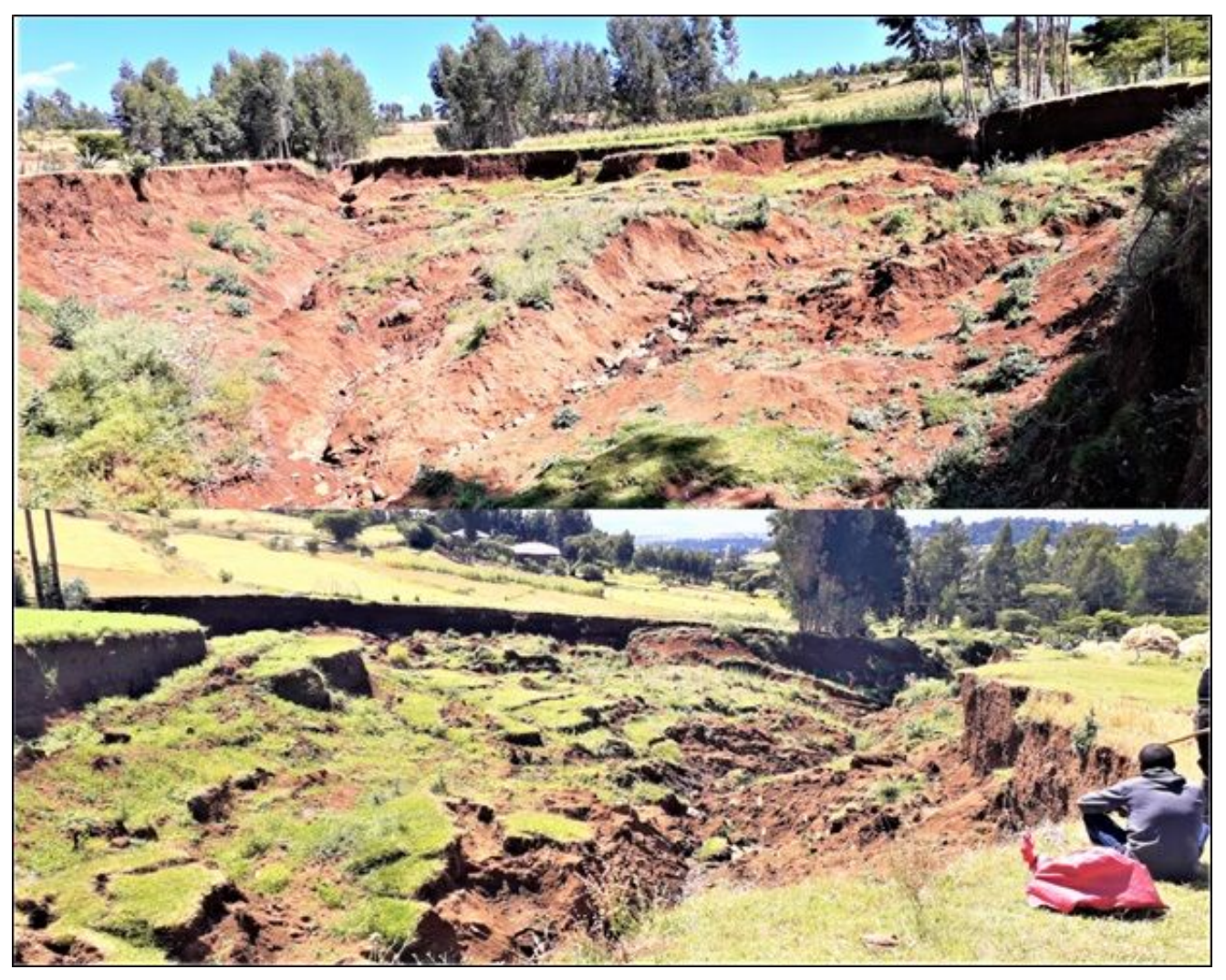

\section{Figure 9}

Soil slide in Debre Yakob area 

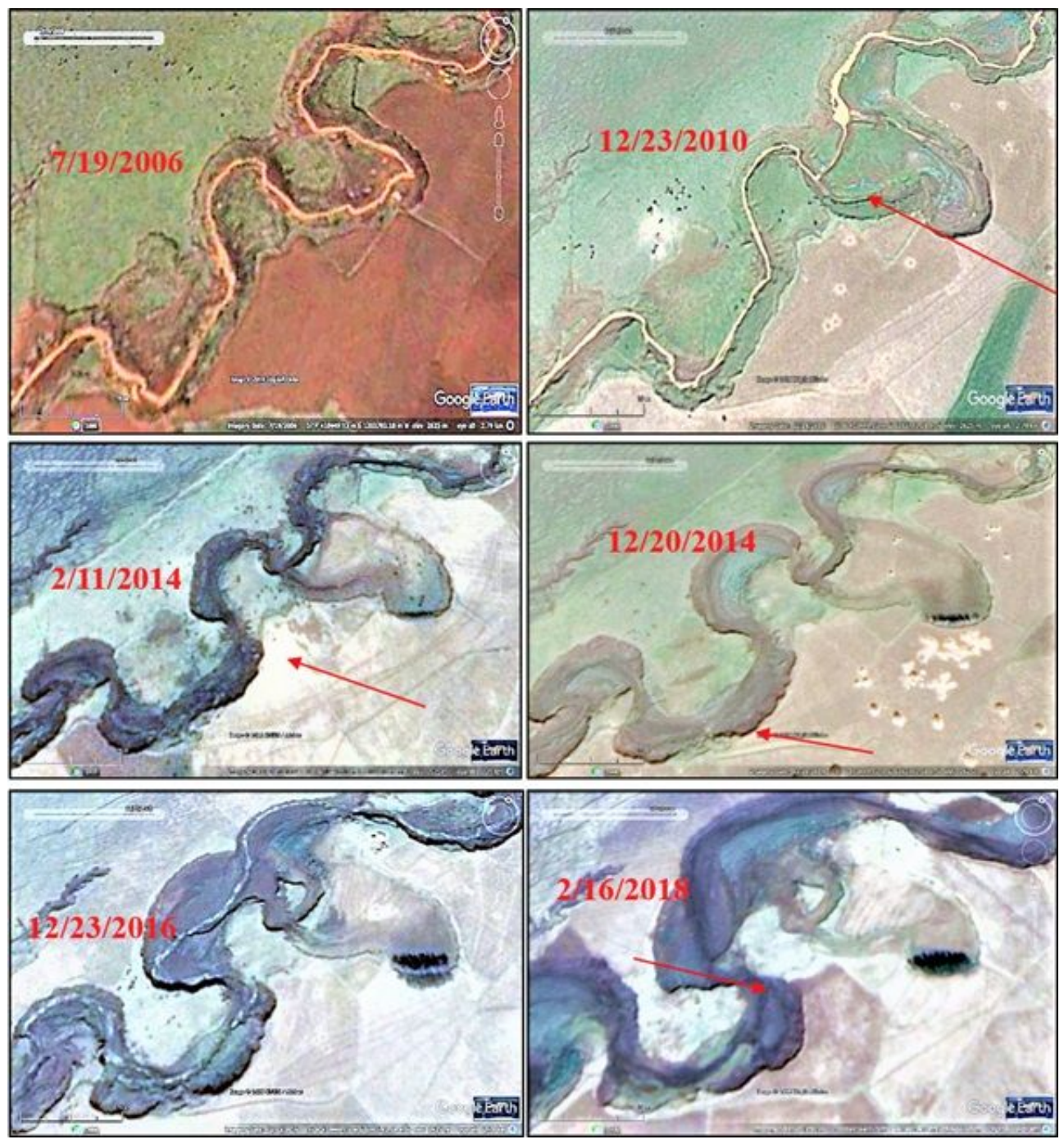

Figure 10

Time series landslide Google Earth image in Debire Birhan area 


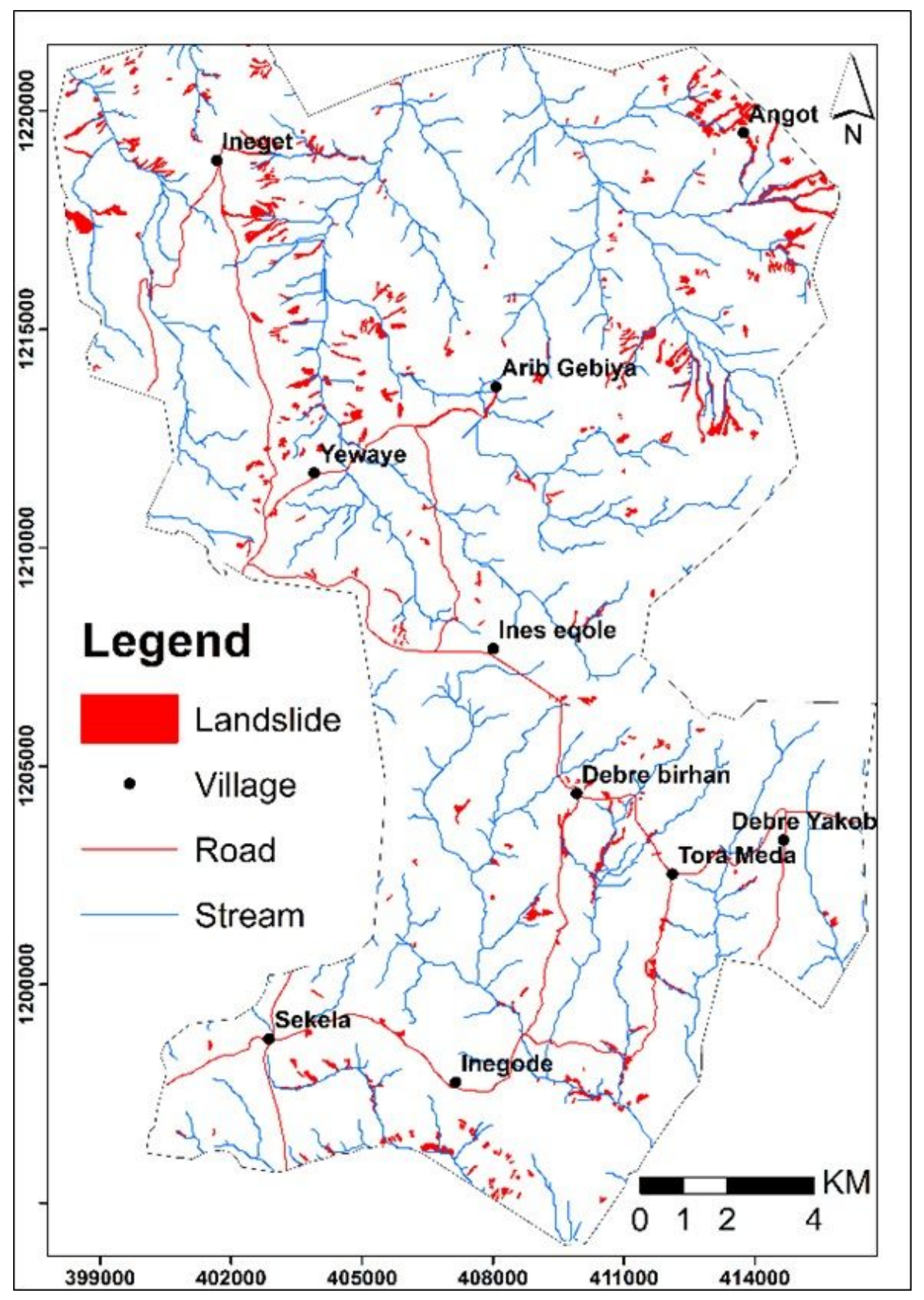

Figure 11

Landslide inventory 

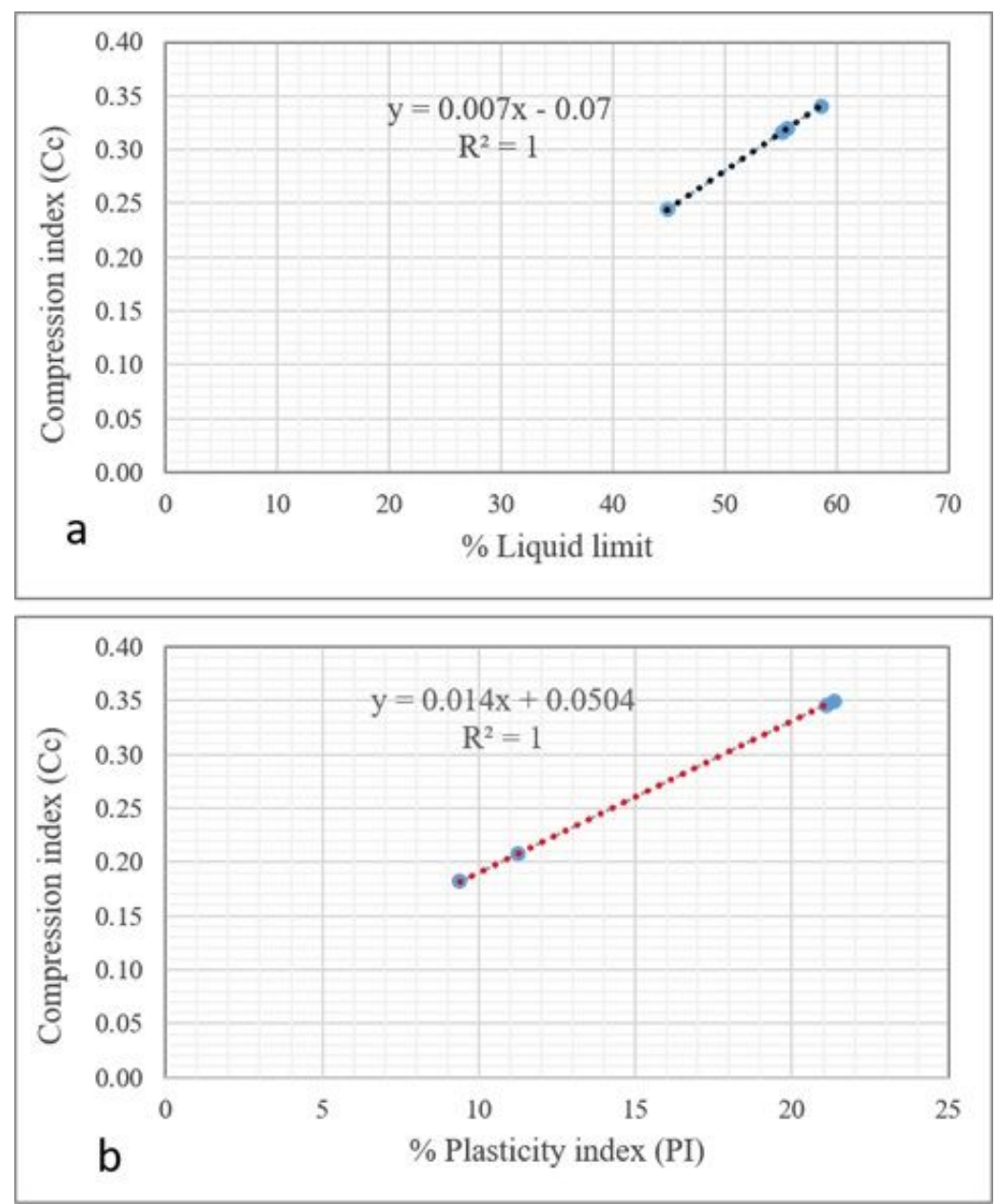

\section{Figure 12}

a) linear regression between $\mathrm{Cc}$ and $\mathrm{LL}$ and b) linear regression between $\mathrm{Cc}$ and $\mathrm{PI}$

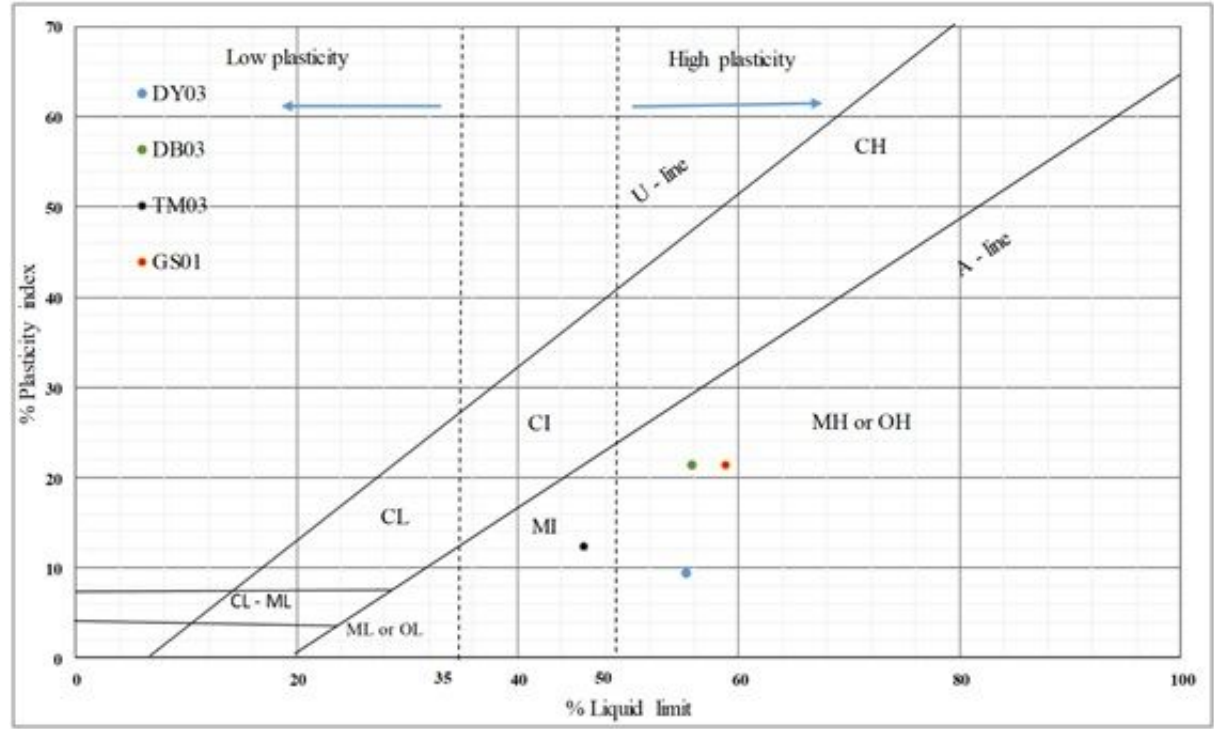

Fig. 13 Plasticity chart

\section{Figure 13}

Plasticity chart 


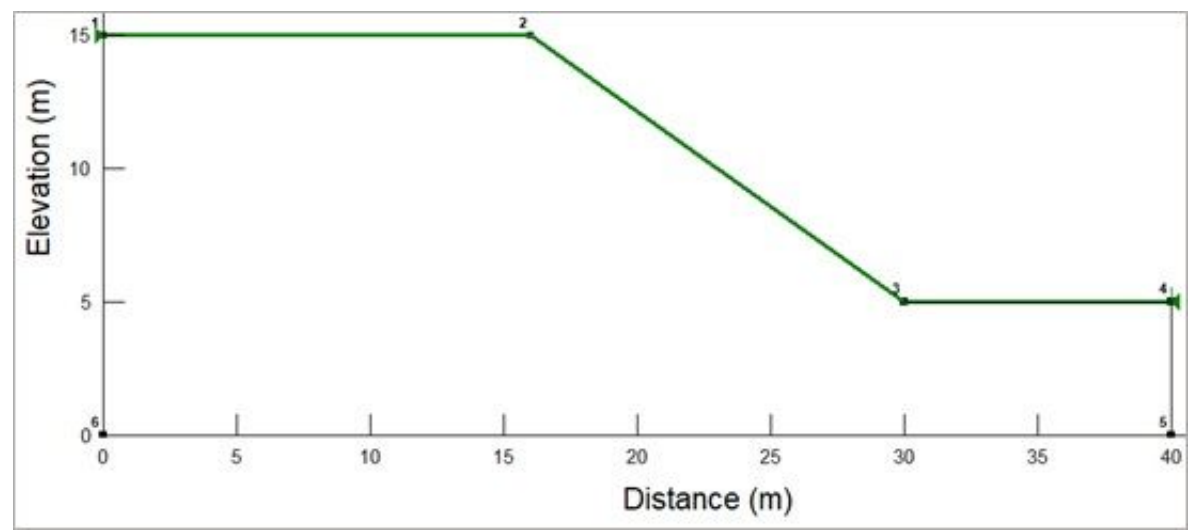

Figure 14

Ideal Geometry

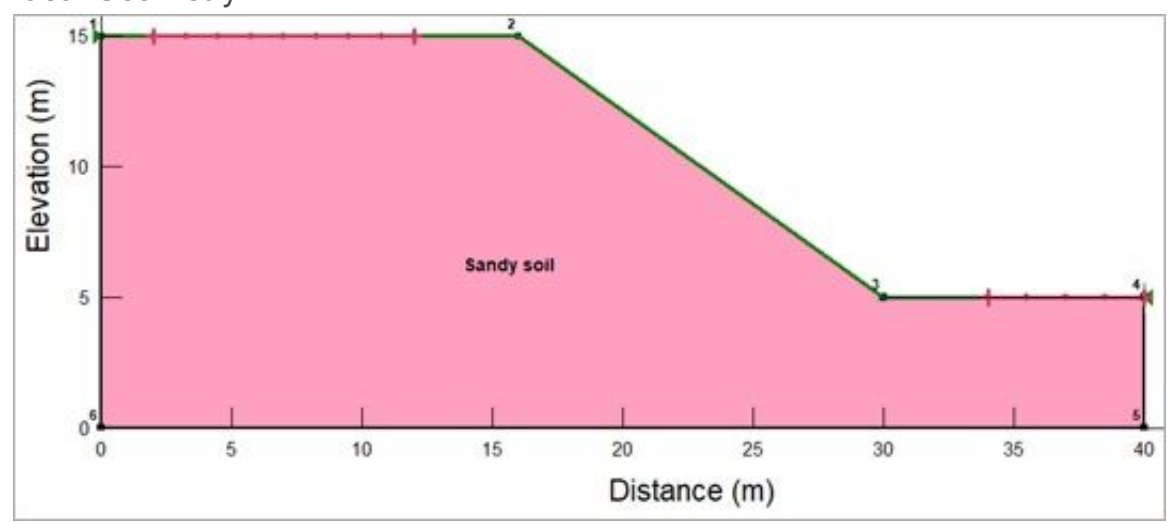

Figure 15

Material Region 


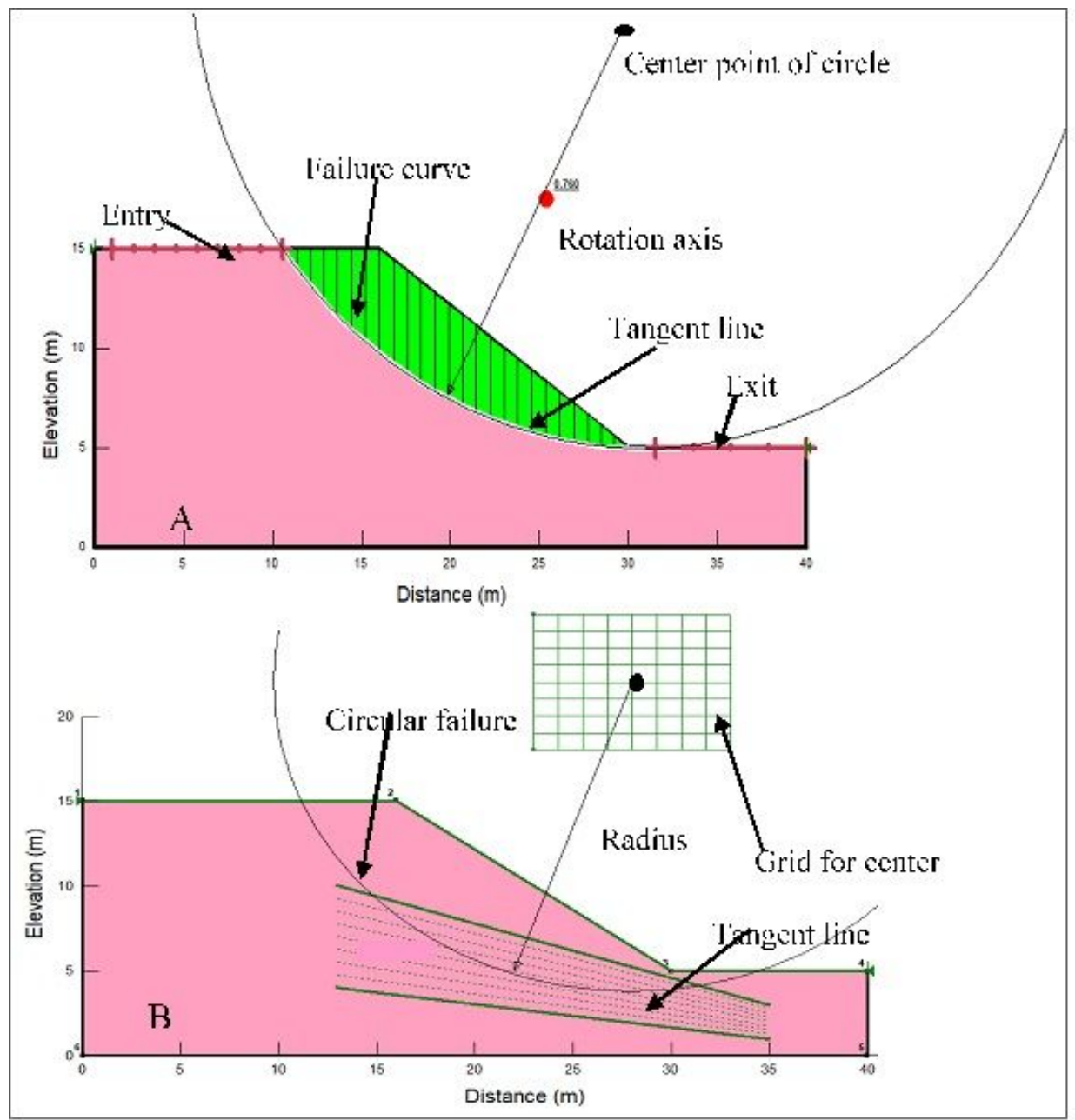

Figure 16

A) Enter and exit and B) Grid and radius

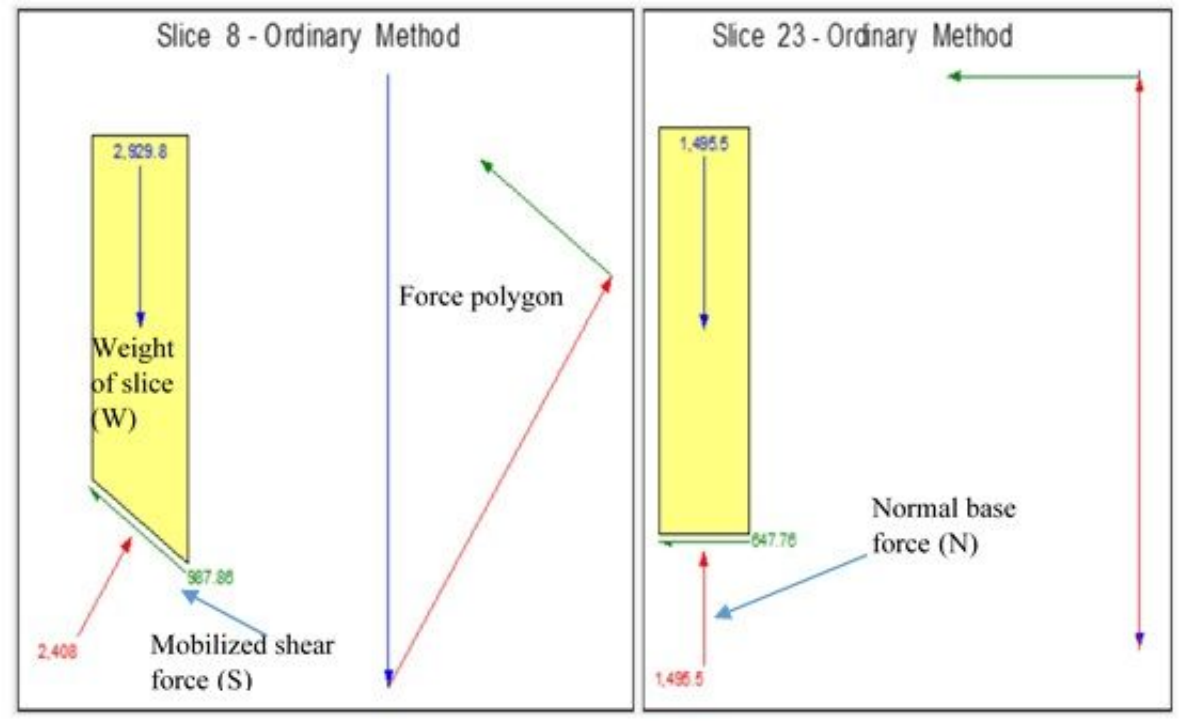

Fig. 17 Free body diagram and Force polygon closure in Ordinary method

\section{Figure 17}

Free body diagram and Force polygon closure in Ordinary method 


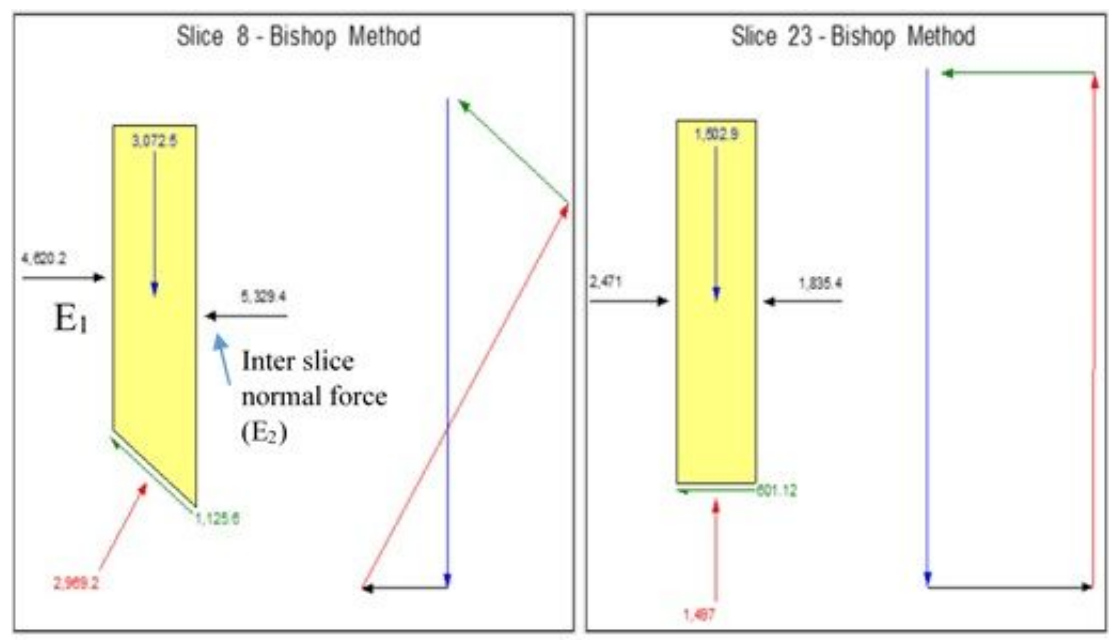

Fig. 18 Free body diagram and Force polygon closure in Bishop's method

\section{Figure 18}

Free body diagram and Force polygon closure in Bishop's method

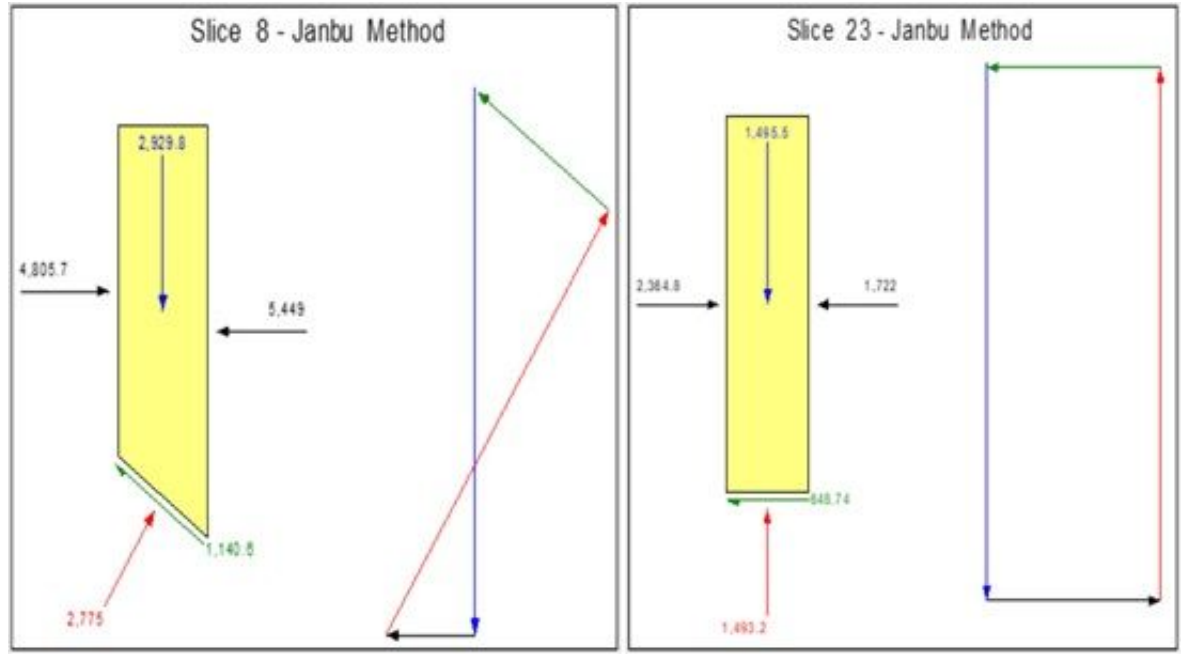

\section{Figure 19}

Free body diagram and force polygon closure in Janbu Method 

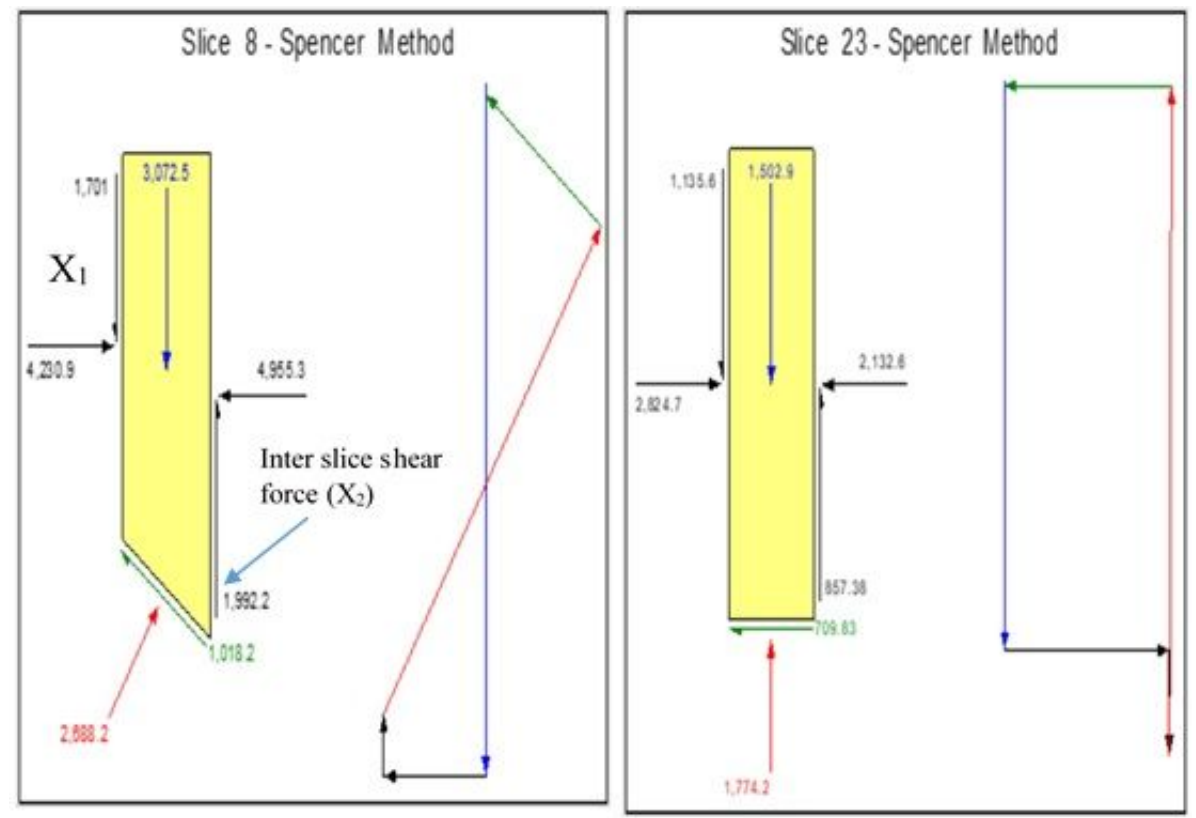

Fig. 20 Free body diagram and force polygon closure in Spencer method

Figure 20

Free body diagram and force polygon closure in Spencer method
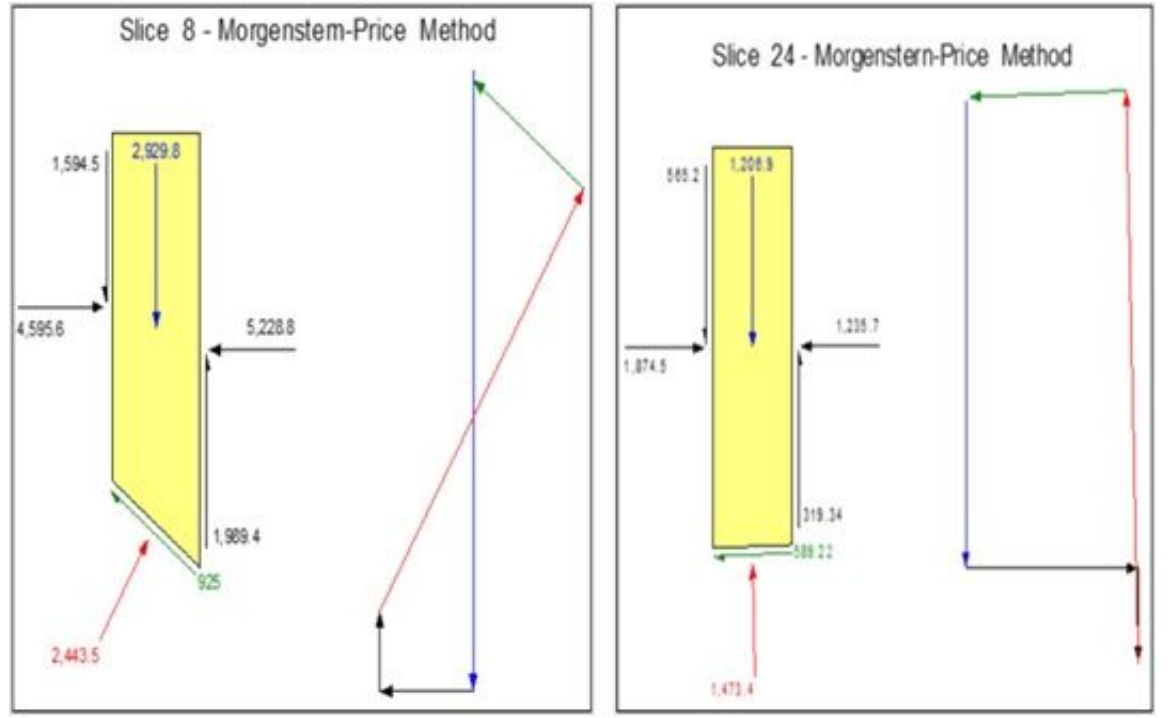

Figure 21

Free body diagram and force polygon closure in Morgenstern price method 


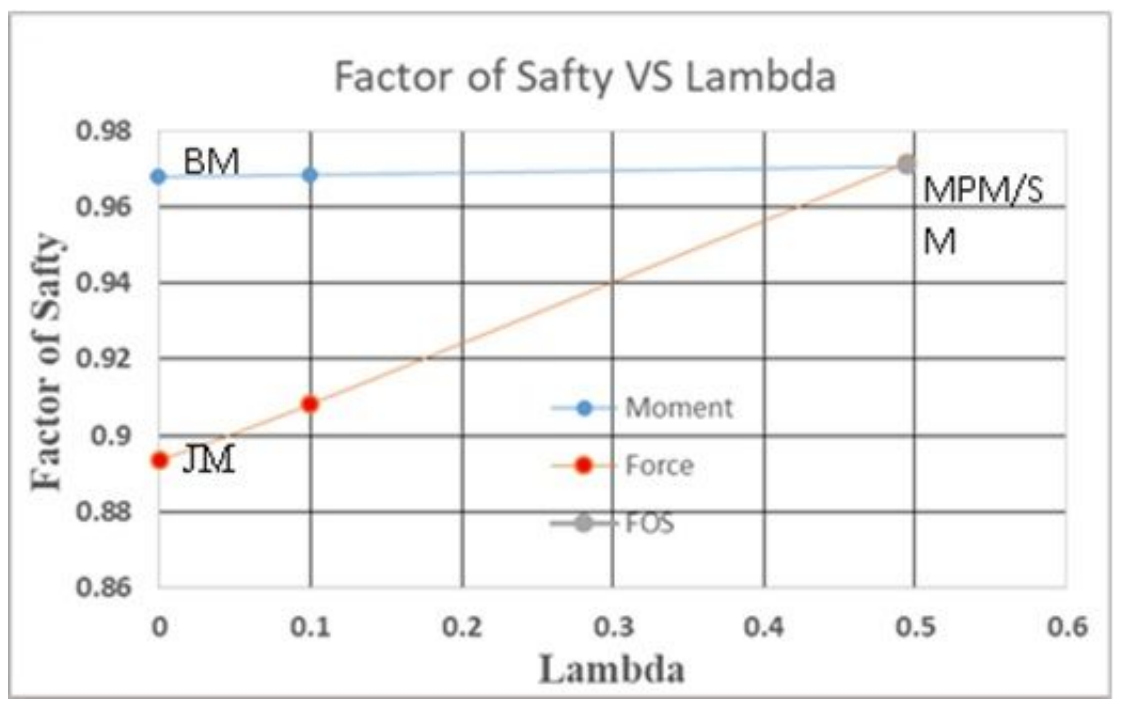

Figure 22

Factor of safety Vs Lambda graph
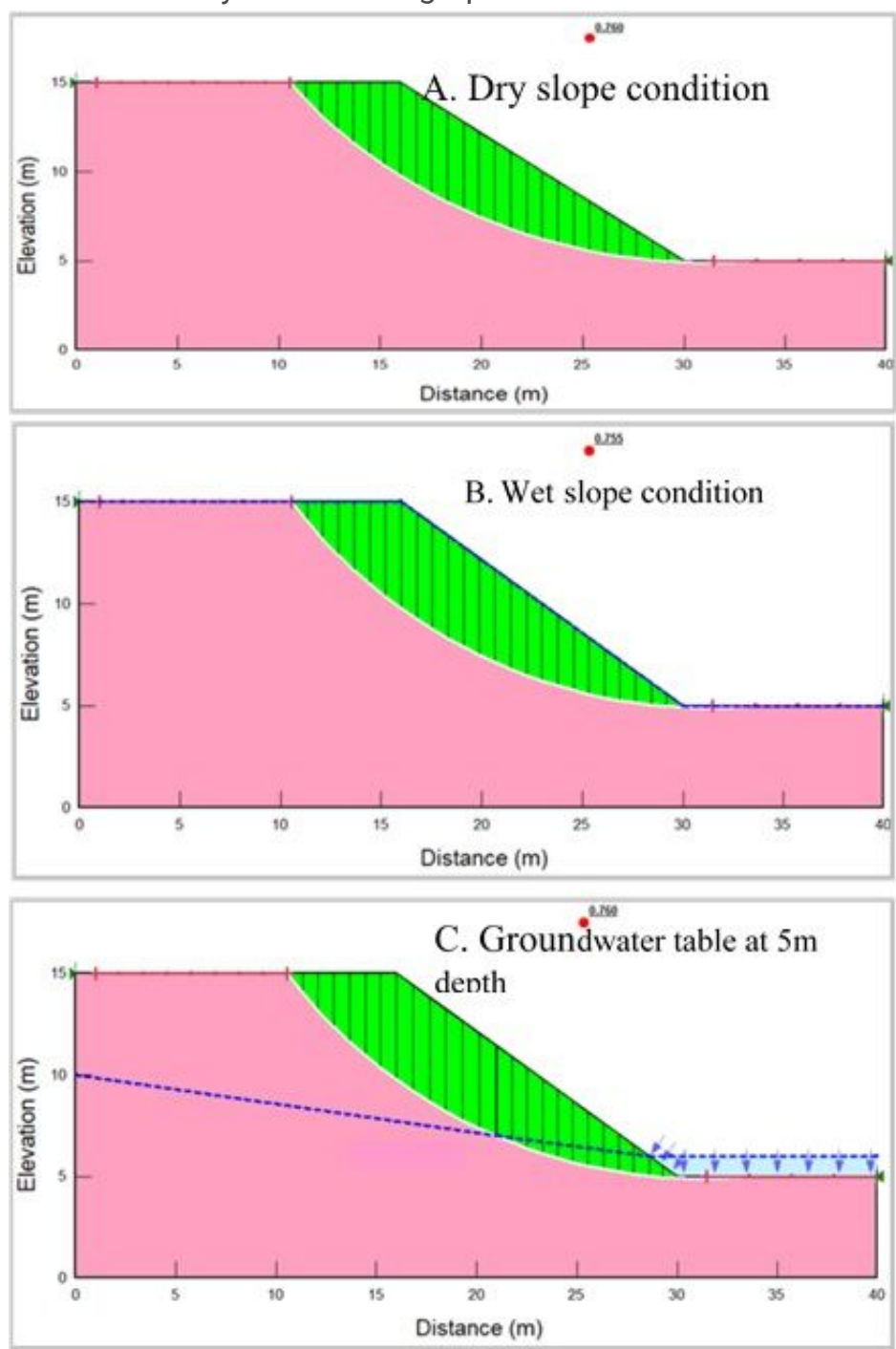

Figure 23

Critical slip failure surface of a slope section at different groundwater conditions 


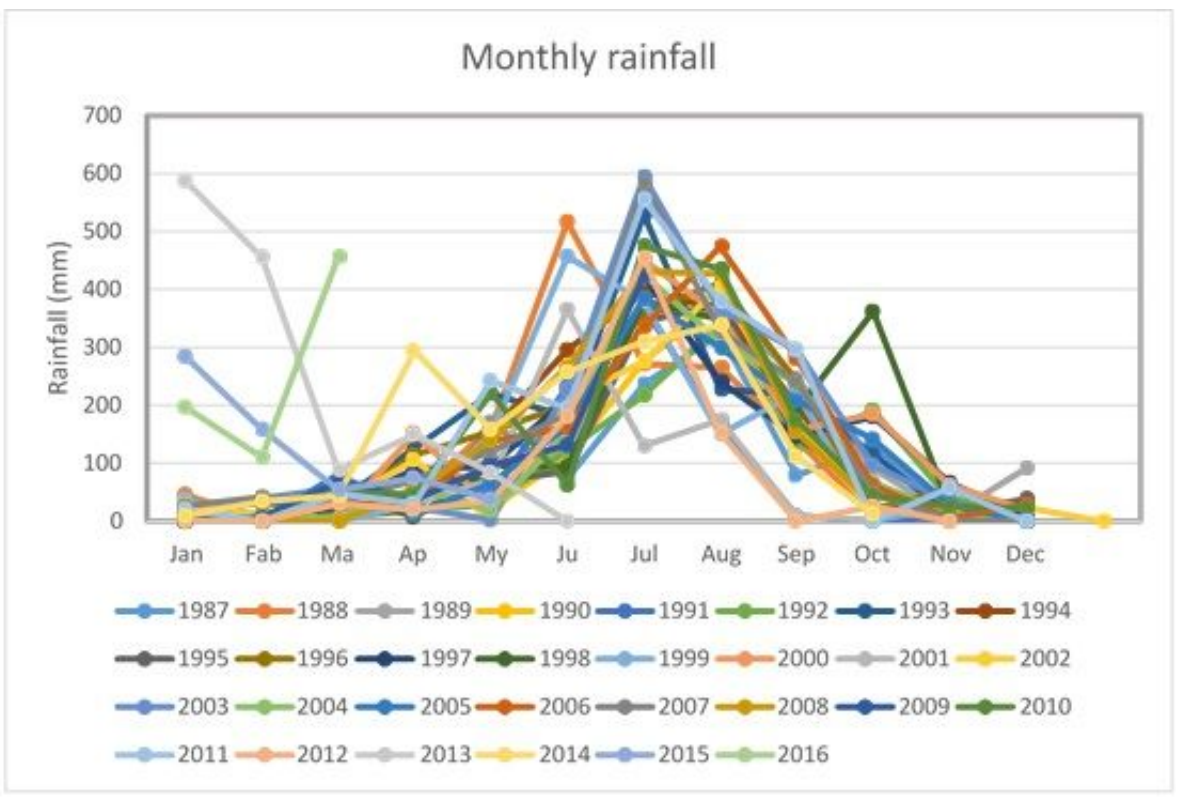

Figure 24 Annual based rainfall

\section{Figure 24}

Annual based rainfall 


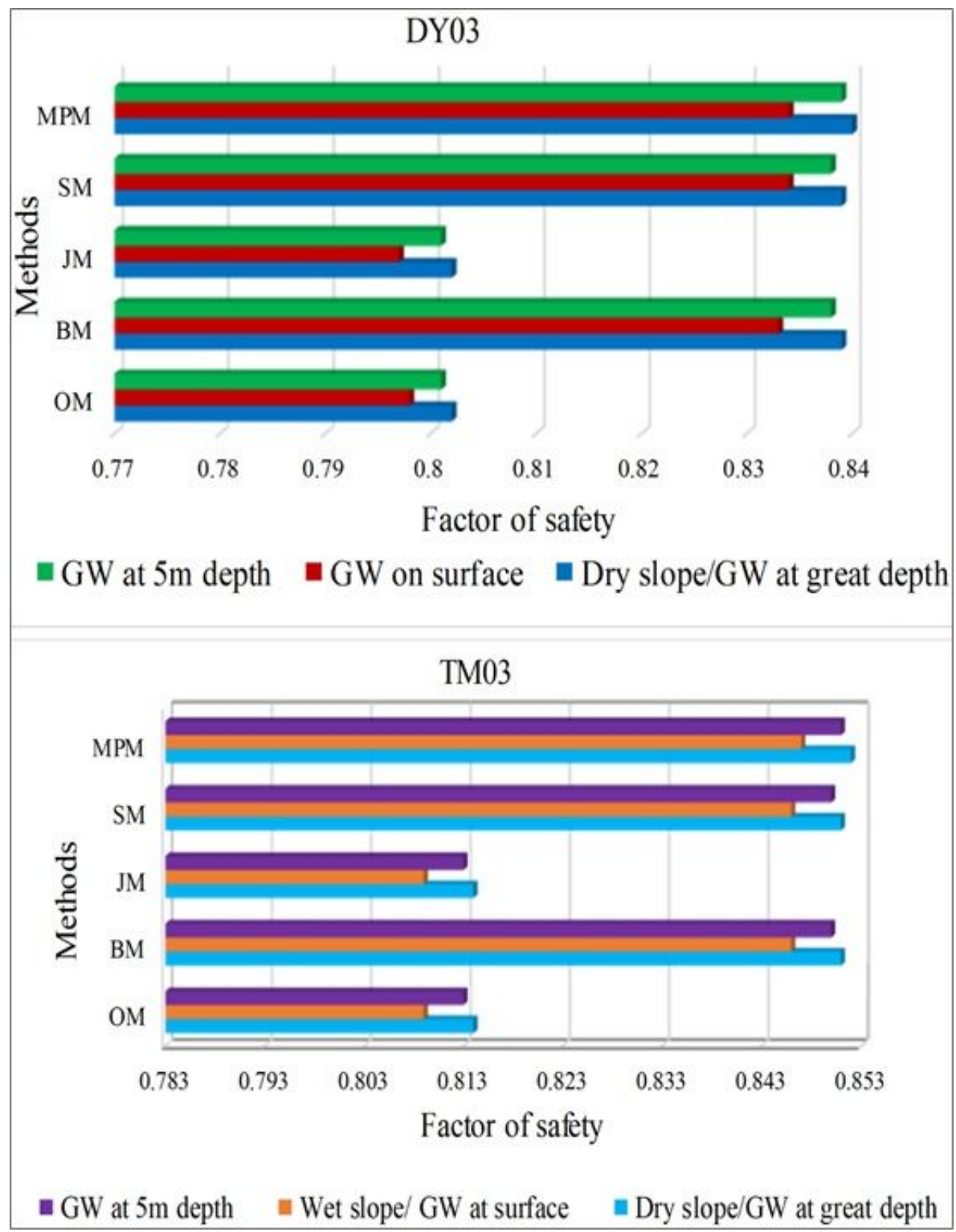

Figure 25

factors of safety comparison with different groundwater conditions 


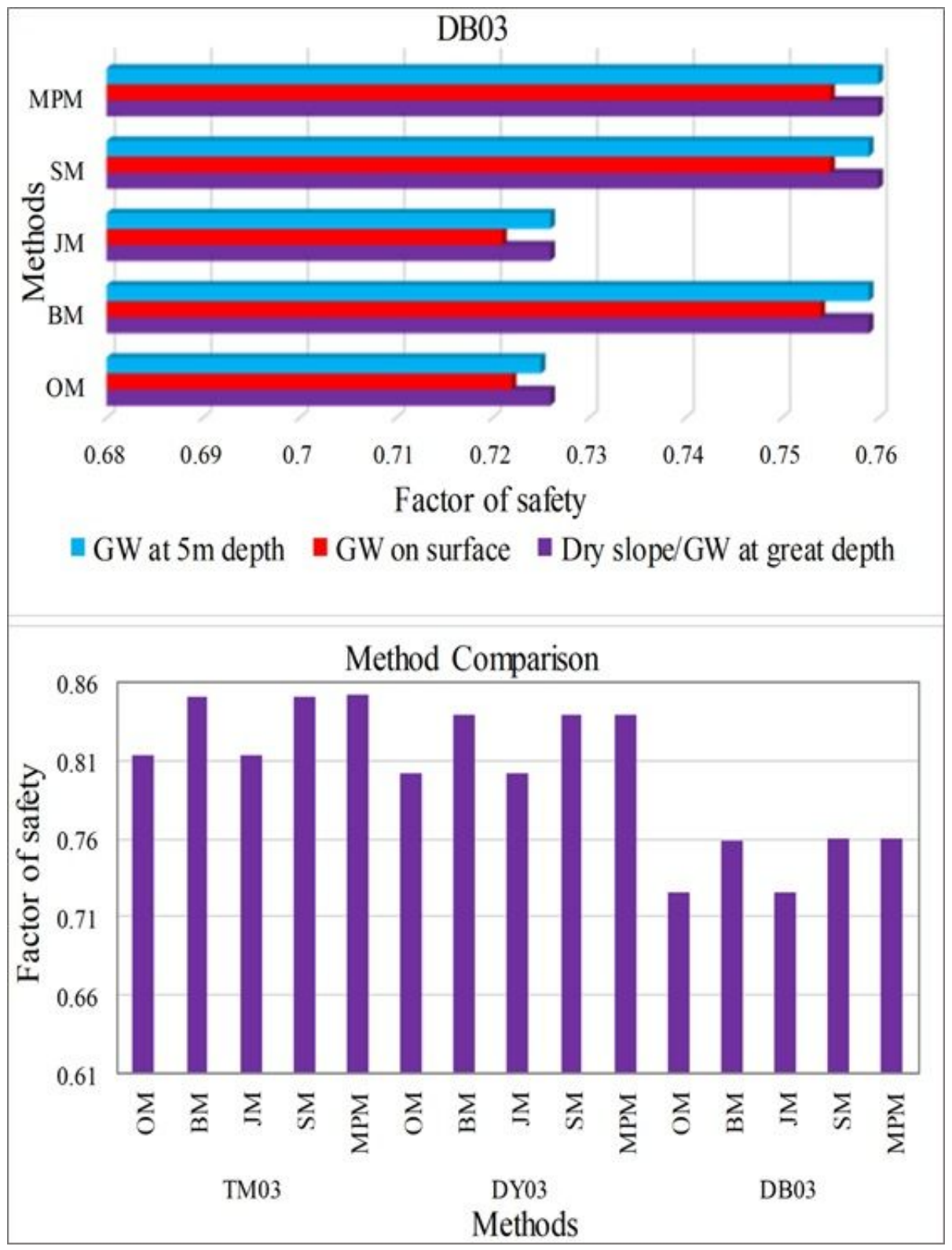

Figure 26

factors of safety comparison among different methods 